\title{
Jazyk, myšlení a kultura
}

\author{
Václav Soukup \\ Ústav etnologie Filozofické fakulty Univerzity Karlovy v Praze \\ Do redakce doručeno 25. ř́jina 2014; k publikaci přijato 9. ledna 2015
}

\section{LANGUAGE, MIND AND CULTURE}

ABSTRACT The object of the study is theoretical analysis of linguistic anthropology as a science which exploring the relationship of language, culture and mind. The aim of this study is to describe and analyze main resources andbasic topics of linguistic anthropology and interpreting results of some researches about how language affects mind. Special attention is paid to the constitution of human language in the course of human evolution and culture.

KEY WORDS language; man; mind; culture; linguistic anthropology

ABSTRAKT Předmětem studie je teoretická analýza lingvistické antropologie jako vědy zkoumající vztah jazyka myšlení a kultury. Cílem studie je popsat a analyzovat jak ideové zdroje a základní tematické okruhy lingvistické antropologie, tak výzkumy věnované vlivu jazyka na myšlení a interpretaci světa. Zvláštní pozornost je věnována konstituování lidského jazyka v průběhu evoluce člověka a kultury.

KLÍČOVÁ SLOVA jazyk; člověk; mysl; kultura; lingvistický relativismus

\section{JAZYK JAKO PǨEDMĚT VÝZKUMŮ LINGVISTICKÉ ANTROPOLOGIE}

Studiem vztahů jazyka, kultury a myšlení v různých společnostech a výzkumem jazyka jako symbolické báze kultury a determinanty lidského chování a prožívání se tradičně zabývá lingvistická antropologie. ${ }^{1}$ Antropologové nepovažují jazyk za izolovaný od společenského života, ale trvají na tom,

1 K lingvistické antropologii blíže: Černý, M.: Homo loquens: Vybrané kapitoly z lingvistické antropologie. Ostravská univerzita, Ostrava 2009; Duranti, A. (ed.): Linguistic Anthropology. CUP, Cambridge 1997; Duranti, A. (ed.): Linguistic Anthropology: A Reader. Blackwell, Oxford 2000; Greenberg, J. H.: Anthropological Linguistics: An Introduction. Random House, New York 1968; Hymes, D.: Language in Culture and Society: A Reader in Linguistic and Anthropology. Harper and Row, New York 1964; Pokorný, J.: Lingvistická antropologie. Grada, Praha 2009; Salzmann, Z.: Jazyk, kultura a společnost. Ústav pro etnografii a folkloristiku AV ČR, Praha 1997; Vrhel, F.: Základy etnolingvistiky. SPN, Praha 1981. že mezi ním a sociokulturními strukturami existuje vzájemná souvislost. Proto analyzují vazby mezi jazykem a systémem hodnot, norem a idejí, které jsou charakteristické pro zkoumanou kulturu. Zvláštní pozornost přitom věnují vlivu jazyka na formování osobnosti v procesu socializace a analýze symbolických systémů sdílených a předávaných př́islušníky určité společnosti. Důvody, které vedou antropology ke studiu jazykových systémů, souvisí se skutečností, že jazyk tvoří symbolickou bázi každé kultury a je základem kognitivních systémů, jež př́slušníci určité společnosti používají k interpretaci sociální zkušenosti a vytváření chování. Prostř̌ednictvím jazyka spolu lidé komunikují, předávají si znalosti a dovednosti, popisují věci, jevy, akce a myšlenky a interpretují realitu. Jazyk je důležitým nástrojem transmise sociokulturních regulativů a kulturních idejí v geografickém prostoru i prostředkem uchování kulturní kontinuity v čase. Obecně je možné konstatovat, že jazyk je základním atributem člověka a jeho výzkum umožňuje hlouběji pochopit lidskou podstatu. V souladu s tradicemi antropologických studií kultury byly 
původně objektem výzkumů lingvistické antropologie jazyky preliterárních společností. Postupně se však spektrum zájmů lingvistických antropologů rozšríílo o vývojové a komparativní studium jazykových systémů moderních společností. Charakteristickým rysem výzkumů současné lingvistické antropologie je důraz na studium řeči a jazyka v konkrétním sociokulturním kontextu.

Předmět výzkumů lingvistických antropologů - jazyk - je možné definovat jako systém znakủ (zvukové nebo písemné povahy) umožňující lidskou komunikaci. Tato definice nepopírá, že komunikace existuje i na subhumánní úrovni, ale explicitně upozorňuje na znakový a symbolický charakter lidské komunikace. Podstatu znaku jako smyslově vnímatelného objektu nebo jevu, který zastupuje, reprezentuje nebo označuje jiné objekty či jevy, lakonicky vymezil již v roce 1934 německý psycholog a průkopník psycholingvistiky Karl Bühler (1879-1963) konstatováním, že znak je něco, co stojí místo něčeho jiného. Teorii znaků a základy sémiotiky rozpracoval americký logik, filozof a matematik Charles Sanders Peirce (1839-1914), který znaky označil za základní elementy lidského myšlení. Peirce při studiu znaků zavedl triádu vzájemně spjatých pojmů objekt, vehikulum a dispozice, jimiž schematicky označil vrcholky relačního trojúhelníku. Objekt představuje konkrétní předmět, o kterém se hovoří, vehikulum slovo, jež daný předmět zastupuje, a dispozice odráží společnou schopnost mluvčího i adresáta přiřazovat zastupující vehikulum $\mathrm{k}$ zástupnému objektu. Peirce na základě vztahu mezi znaky a objekty, které označují (zastupovanou skutečností), vytvořil klasifikaci, jež znaky dělí na „ikony“, „indexy" a „symboly“. U ikonů je vztah mezi označujícím znakem a označovaným (objektem nebo jevem) založen na skutečné podobnosti. Ikony např́iklad vystupují v podobě realistických obrazů, fotografí, map, soch, piktogramů aj. Typickou ukázkou ikonu může být stylizovaná dětská kresba slunce nebo stromu vykazující obrazovou podobnost mezi znakem a zobrazeným objektem. Jako př́klad ikonu lze uvést také onomatopoické (zvukomalebné) citoslovce. $\mathrm{Za}$ indexy (příznaky, symptomy) Peirce označil třídu znakủ, vyjadřující určitou př́ćinnou nebo věcnou souvislost věcí a jevů nebo částí a celku. Např́klad kouř je indexem ohně apod. Jako symboly vymezil znaky, jejichž podoba nevykazuje žádnou podobnost nebo kauzalitu $\mathrm{k}$ jevům nebo objektům, které označují, nebot jejich vzájemný vztah je zcela arbitrární. Symboly reprezentují tř́du znaků, jejichž podoba a význam vznikly a jsou sdíleny na základě konvence a vztah označujícího a označovaného je dán dohodou. Americký antropolog českého původu Zdeněk Salzmann (nar. 1925) v této souvislosti mluví o arbitrárnosti - neexistenci vnitřního vztahu mezi formou významové jednotky jazyka a objektem či jevem, který jednotka zastupuje. ${ }^{2}$ Typickou ukázkou symbolu je psané nebo mluvené slovo. Slova (symboly), tvořící lidský jazyk, jsou kombinacemi zvuků vystupujících v podobě významotvorných hlásek, jimž př́slušníci určitého jazykového

2 Salzmann, Z.: Jazyk, kultura a společnost. Ústav pro etnografii a folkloristiku AV ČR, Praha 1997, s. 28. společenství přikládají obecně zavedený a sdílený význam. Každý jazyk obsahuje konečný počet slov spojených s jedním nebo více významy. Soupis všech slov, která daný jazyk obsahuje, se nazývá „lexikon jazyka“. Studujeme-li jazyk jako znakovou soustavu sloužící ke komunikaci, je možné postihnout jeho tř̌ základní dimenze prostřednictvím sémiotické analýzy. Podle amerického filozofa Williama Charlese Morrise (1903-1979), který programově navázal na dílo Charlese Peirce, sémiotika jako věda o znacích zahrnuje tři základní subdisciplíny - sémantiku, syntaktiku a pragmatiku. Sémantika se zabývá studiem významu znakových soustav, syntaktika zkoumá vzájemný vztah znaků - pravidla jejich skladby (gramatiku) - a pragmatika analyzuje vztah znaků $\mathrm{k}$ uživateli. Kromě sémiotiky hrají při studiu jazyka významnou roli také lingvistická fonologie a morfologie. Předmětem fonologie je výzkum zvukové stránky přirozeného jazyka, zejména studium funkcí hlásek a pravidel jejich spojování do podoby jazykových struktur, které jako celek vytvárejí fonologický systém. Základní jednotkou fonologické analýzy je foném, jejž lze definovat jako nejmenší zvukovou jednotku, která umožňuje mezi sebou odlišit různá slova. Fonologie, na rozdíl od fonetiky, jež zkoumá výhradně akustickou, auditivní a artikulační stránku jazyka, studuje zvukový systém jazyka i $z$ hlediska schopnosti fonémů rozlišit význam větších celků. Předmětem lingvistické morfologie (tvarosloví) je výzkum hláskových kombinací, jejich sledů a pravidel, podle kterých jsou vytvářeny základní, dále nedělitelné, sémantické jednotky. Základní jednotkou morfologické analýzy je morfém, který lze definovat jako nejmenší vydělitelnou sémantickou jednotku - část slova, které je nositelem věcného nebo gramatického významu. Morfologie studuje jak inventář nejmenších, význam modifikujících jazykových výrazů, tak pravidla, podle nichž se tyto jazykové jednotky užívají a spojují, aby vytvorily slova.

Na lidském jazyce je úžasná jeho schopnost spojovat konečné množství slov do nekonečného počtu smysluplných vět. Znalost lingvistických pravidel - gramatiky mateřského jazyka, jejímž prostřednictvím se základní jazykové prvky (hlásky a slova) skládají do vyšších významových celků - je přitom nevědomá a její použivání je intuitivní. Již v průběhu prvního až třetího roku života si děti osvojí tisíce symbolů a slov, které dokážou podle gramatických pravidel správně spojovat do větných celkủ. Proto také rodilí mluvčí nemusí dlouho a složitě přemýšlet o tom, jak správně vytvořit ve své mateřštině větu nebo porozumět nějakému sdělení. Skutečnost, že se děti učí rodný jazyk bez zjevného úsilí, se pokusil vysvětlit americký lingvista židovského původu Avram Noam Chomsky (nar. 1928) prostřednictvím teorie o vrozených předpokladech, umožňujících osvojit si v raném dětství jazyk. Chomsky je přesvědčen, že existuje geneticky zabudovaná, vrozená „univerzální gramatika“, která dětem umožňuje, aby se jako rodilí mluvčí naučily v poměrně krátké době správně mluvit jakýmkoli světovým jazykem. Jinými slovy, všechny děti mají vrozenou schopnost rozeznávat syntaktické vztahy mezi jednotlivými složkami pronesené věty - „hloubkovou strukturou" skrytých gramatických spojení. Proto snadno 
chápou sémantické důsledky toho, když se jedna větná forma přemění na jinou, např́klad transformaci oznamovací věty $\mathrm{v}$ otázku a bez problémů tyto jazykové operace provádějí. Noam Chomsky, v opozici k behavioristické teorii učení a předpokladu, že mysl novorozence je „tabula rasa“, předpokládá, že někde v lidském mozku je skryta specializovaná neuronová struktura, fungující jako prostředek pro osvojení jazyka a vrozený modul jazykového vývoje („Language Acquisition Device“ - LAD). Tento geneticky naprogramovaný mechanismus, usnadňující ontogenetický jazykový vývoj, umožňuje dětem rozlišovat, „jak se věci a činnosti, reprezentované jmennými a slovesnými částmi věty, $\mathrm{k}$ sobě vztahují jakožto činitel, činnost a objekt“. ${ }^{3}$ Existenci „transformační gramatiky“ potvrzuje i rychlost, s níž si malé děti jazyk osvojují, a skutečnost, že všechny děti procházejí stejnými univerzálními stadii vývoje jazyka. Dokonce i neslyšící děti žvatlají ve stejnou dobu jako děti slyšící. Pro platnost Chomského teorie svědčí také transkulturní lingvistické výzkumy, které prokázaly, že různé jazyky obsahují jazykové univerzálie, jako jsou např́iklad př́idavná a podstatná jména. Chomského „teorie LAD“, předpokládající, že lidé disponují geneticky podmíněnou schopností osvojit si, rozumět a generovat libovolný jazyk, výrazně ovlivnila výzkumy v oblasti psycholingvistiky, sociolingvistiky, lingvistické antropologie a kognitivních věd.

Významnou charakteristikou jazyka je symboličnost slov a vět, která umožňuje hovořit a přemýšlet o věcech a jevech, jež nejsou empiricky registrovatelné nebo jsou v čase i prostoru vzdálené. Proto můžeme např́klad mluvit o člověku, který není právě přítomen, nebot jazykové symboly umožňují v naší mysli představu této osoby vyvolat. Prostřednictvím jazyka je možné vytvářet i svět, který existuje výhradně v lidské fantazii. Proto se součástí lidské kultury staly pohádky a mýty, detailně popisující kouzelné skřítky, neviditelné duchy, mocné bohy či zlé démony. Symboličnost jazyka nalezla své vyjádření také $\mathrm{v}$ umělém jazyce vědy. Např́iklad matematické symboly vědcům umožňují popisovat a analyzovat jevy, procesy a zákonitosti, jež se v našem reálném fyzikálním světě nevyskytují, ale hypoteticky mohou existovat $\mathrm{v}$ alternativní realitě. Klasickým př́kladem může být Einsteinova teorie relativity lapidárně vyjádřená rovnicí $E=m c^{2}$. Lidská schopnost zmocňovat se světa prostřednictvím sítě pojmů a kategorií vedla kulturní antropology k formulování hypotézy, podle níž kultura představuje symbolickou konstrukci - systém symbolů a významů, jejichž prostřednictvím lidé interpretují své chování i realitu, která je obklopuje. Studium jazyka se tak stalo důležitým klíčem k pochopení významů, jež lidé v dané společnosti přičítají světu, a tedy i podstatě zkoumané kultury.

Jazyk jako předmět výzkumu lingvistické antropologie představuje komplexní fenomén, pro který je charakteristická celá řada atributů. Proto je nezbytné jej studovat $\mathrm{z}$ hlediska jeho různých charakteristik a respektovat skutečnost, že jazyk je svojí podstatou:

3 Hunt, M.: Dějiny psychologie. Portál, Praha 2000, s. 509.
1. Komunikativní - umožňuje sdělování symbolických obsahů a přenos idejí mezi lidmi, kteří daným jazykem hovoří.

2. Symbolický - vztahy mezi znaky a označovanými jevy nebo objekty jsou arbitrární povahy.

3. Strukturovaný - symboly tvořící jazyk jsou uspořádány podle gramatických pravidel.

4. Multidimenzionální - strukturu jazyka lze analyzovat na mnoha sémantických, syntaktických a pragmatických úrovních.

5. Generativní - schopnost produkovat nové věty je v rámci jazykové struktury prakticky neomezená.

6. Dynamický - jazykové systémy se nepřetržitě vyvíjejí, modifikují a přetvářejí. ${ }^{4}$

Všechny výše uvedené atributy jazyka mohou být zkoumány jako relativně samostatná dimenze nebo studovány jako komplexní celek. Jedním ze zásadních přínosů lingvistické antropologie je snaha této disciplíny studovat jazyk z holistické perspektivy, jako integrovaný kognitivní a znakový systém, který je nedílnou součástí každé kultury.

Poprvé si antropologové a antropoložky uvědomili význam studia jazyků ze zcela praktických důvodů. Realizace antropologického terénního výzkumu od výzkumníka vyžadovala schopnost komunikovat se svými informátory v jejich mateřrštině, nebot práce $s$ tlumočníky často vedla ke zkreslení získaných informací. Proto se součástí přípravy na terénní výzkum stala výuka jazyka zkoumaných domorodců, která pokračovala i v době antropologova pobytu v terénu.

Rozvoj lingvistické antropologie urychlila na počátku 20. století snaha antropologů získat informace o mizícím světě preliterárních společností včetně jejich jazyků. Proto se američtí antropologové zaměřili na studium slovní zásoby a gramatiky indiánských jazyků s cílem uchovat informace o jejich existenci budoucím pokolením. Jedním $\mathrm{z}$ důsledků výzkumu domorodých jazyků bylo, že si antropologové uvědomili úzké sepětí jazyka a kultury studované společnosti. $\mathrm{V}$ ohnisku výzkumů americké lingvistické antropologie se tak ocitlo testování teorie lingvistického relativismu (Sapirova-Whorfova hypotéza), podle níž jazyk (slovní zásoba a gramatika) determinuje vnímání a interpretaci světa. Mezi konkrétní podněty, které podnítily zájem antropologů o studium vztahů mezi jazykem, myšlením a kulturou, patřilo zejména zjištění, že jazyk hraje důležitou roli jako nástroj vnímání, klasifikace a konstrukce významů, kterou lidé přikládají prrírodní a sociokulturní realitě. Při studiu preliterárních společností si antropologové např́íklad uvědomili, že slovní zásoba, konkrétně preferované pojmy a kategorie, svědčí o tom, jaká třída věcí a jevů je pro prríslušníky určité kultury důležitá. Skutečnost, že slovní zásoba zrcadlí potřebu určité skupiny lidí komunikovat o některých objektech, kvalitách a činnostech více než o jiných, lze doložit i v moderní společnosti na lidech, kteří sdílí stejnou

4 Srov. Sternberg, R. J.: Kognitivní psychologie. Portál, Praha 2002, s. $318-320$. 
profesní subkulturní zkušenost. Jako př́klad lze uvést slovní zásobu profesionálního automechanika, který dokáže pojmenovat a specifikovat stovky automobilových součástek a jejich funkcí na rozdíl od pouhého uživatele automobilu, jehož verbální kompetence je $\mathrm{v}$ této oblasti nesrovnatelná. Specializované slovní zásoby plní utilitární a adaptivní funkci, nebot' příslušníkům určité sociální skupiny umožňují efektivní a jednoznačnou komunikaci. Současně symbolicky posilují sociální status lidí, kteří danou profesní jazykovou kompetencí disponují. Existují dokonce profese, kde mistrné zvládnutí specializované slovní zásoby a schopnost jejího „překladu“ pro širokou laickou veřejnost funguje jako mobilitní výtah, který uživatelům současně umožňuje kumulovat ekonomický kapitál a posilovat svůj odborný status. Jedná se např́klad o obhájce, jejichž úspěch je závislý na mistrovském zvládnutí právnické terminologie a schopnosti jejího výkladu na konkrétní soudní prrípady.

Snaha antropologů objasnit, jak lidé $\mathrm{v}$ různých kulturách prostřednictvím kognitivních systémů a jazykových kategorií vnímají, klasifikují a organizují realitu, vedla ve druhé polovině 20. století ke vzniku kognitivní antropologie a jejích subdisciplín, etnovědy a etnosémantiky. Proto se při studiu cizích kultur staly předmětem výzkumů lingvistických antropologů nativní klasifikační soustavy („folktaxonomie“) a sémantické oblasti („domény“), jež vyjadřovaly podstatné hodnoty, normy a ideje studované kultury. Důraz na studium jazyka je typický také pro symbolickou antropologii, která ve druhé polovině 20. století učinila dominantním předmětem antropologických výzkumů kulturu, vymezenou jako systém symbolů a významů sdílených členy určité kultury. Paralelně s kognitivní a symbolickou antropologií se rozvíjel také výzkumný směr označovaný jako etnografie řeči (etnografie komunikace) zabývající se studiem řečových aktů v konkrétní sociální situaci a kulturním kontextu.

Výzkum vztahu jazyka, myšlení a kultury jako předmětu lingvistické antropologie přispěl také k rozvoji antropologické metodologie. $\mathrm{K}$ tvořivému uplatnění jazykovědných metod $\mathrm{v}$ antropologii např́klad došlo při vzniku jednoho z nejvýznamnějších směrů druhé poloviny 20 . století - francouzské strukturální antropologie. Jak přiznává zakladatel strukturalismu, francouzský sociální antropolog Claude Lévi-Strauss, zásadním podnětem pro vytvoření základů strukturální metodologie mu byly poznatky Pražského lingvistického krouž$k u$, konkrétně principy fonologie, které formuloval ruský lingvista Roman Osipovič Jakobson (1896-1982). Inspirativní dialog mezi strukturální antropologií a lingvistikou pokračoval i v době vrcholného strukturalismu, kdy se ve své interpretaci nativních mytologií amerických indiánů Lévi-Strauss inspiroval teorií transformační gramatiky amerického lingvisty Noama Chomského. V americké antropologii nalezla lingvistika své uplatnění zejména $\mathrm{v}$ rámci kognitivní antropologie, která učinila významným nástrojem antropologické analýzy kultur metodu komponentní analýzy. V průběhu existence antropologie se tak aplikace lingvistických metod na studium kultury stala jedním ze základních atributů lingvistické antropologie.

\section{IDEOVÉ ZDROJE LINGVISTICKÉ ANTROPOLOGIE}

Zájem vědců o studium vzniku, vývoje a fungování jazykových systémů má poměrně dlouhou tradici. Ponechme stranou biblický příběh o „zmatení jazykü“ při budování babylonské věže, i př́iběh o egyptském vladaři, který se pokusil zjistit, jaká první slova řeknou děti, které nechá vychovávat bez kontaktu s lidským jazykem. Důležité je, že již ve starověku a stř̌edověku vznikla řada prací svědčících o odvěkém zájmu učenců o různé dimenze lidského jazyka. Významnou roli při formování novověké vědy o jazycích znamenal vynález knihtisku, který posílil svébytnost evropských národních jazyků a přispěl $\mathrm{k}$ tomu, že latina postupně ztrácela status mezinárodního jazyka. V 15. a 16. století vznikaly první gramatiky jazyků, jako byla např́klad toskánština (1441), španělština (1492) a francouzština (1530). Pád středověkého univerzalismu se promítl do vztahu evropských učenců $\mathrm{k}$ jejich rodnému jazyku, který neváhali ve stále větší míře obhajovat a v mezinárodním kontextu také propagovat. Vysokou prestiž si získala především francouzština, kterou francouzští učenci, spjatí s filozofí́ racionalismu, označili za ,jazyk rozumu“. Na zvýšení zájmu o systematické studium cizích jazyků mají svůj podíl také zámořské objevy nových zemí, jako byla Amerika. Následná evropská koloniální expanze, spojená se šířením křrestanství, vyvolala $\mathrm{v}$ rámci misijního hnutí potřebu znalosti domorodých jazyků jako nástroje efektivního ovládnutí cizokrajných etnik a národů prostřednictvím víry. Evropští misionáři zaznamenali řadu indiánských gramatik, i když je třeba poznamenat, že jejich zájem o studium domorodých jazyků nevyvolal čistě vědecký zájem, ale především snaha podpořit šíření křestanských náboženských hodnot a s nimi spjatých vzorců chování.

Při utváření základů novověké jazykovědy sehrál významnou roli také evropský filozofický racionalismus a empirismus. Přestože se jedná o dvě odlišné linie filozofického myšlení, tyto učence spojovala snaha pochopit kognitivní funkce jazyka. V 18. století anticipoval vznik jazykovědy zejména německý osvícenský filozof Johann Gottfried Herder (17441803). Herder ve svých úvahách nad filozofií dějin kladl důraz na roli, kterou při formování lidské kultury sehrál jazyk jako nástroj adaptace $\mathrm{k}$ vnějšímu prostředí. Svým tvrzením, že všechny jazyky jsou odvozeny z jednoho prajazyka, otevřel dlouholetý spor mezi zastánci monogenetické teorie, podle níž mají všechny jazyky společný původ, a prŕivrženci polygenetické teorie, kteří předpokládali, že jednotlivé jazyky pochází $\mathrm{z}$ různých, na sobě nezávislých zdrojů.

Mezi autory, kteři přispěli ke konstituování synchronně koncipované komparativní lingvistiky, patřil německý filozof, diplomat a jazykovědec Wilhelm von Humboldt (1767-1835). Tento všestranný učenec a znalec evropských i neindoevropských jazyků dospěl na základě studia širokého spektra asijských, indonéských, polynéských a indiánských jazyků k názoru, že každý jazyk obsahuje svou vlastní vnitřní jazykovou formu vystupující v podobě specifického typologického profilu, syntaktických struktur a sémantických principů, které aktivně podmiňují a utvářejí lidské myšlení. Humboldt na jazyk 
pohlížel jako na proces tvưrčí činnosti a aktivující sílu, jejiž struktura tvoří podstatu národního ducha („Volksgeist“) a národního charakteru („Nationalcharakter“). Jazyk jako výraz národní mentality podle jeho názoru opisuje kolem každého národa kruh, $\mathrm{z}$ něhož nelze vystoupit jinak než vstupem do jiného kruhu. Humboldt originálním způsobem anticipoval teorii lingvistického relativismu. Byl totiž přesvědčen, že lidé spoutaní tvořivou aktivující silou svých rodných jazyků v různých jazykových společenstvích vykazují specifický pohled na svět (,Weltansicht") a pod vlivem struktury daného jazyka odlišně vnímají a interpretují realitu. $\mathrm{V}$ jistém smyslu lze Humboldta označit také za předchůdce zastáncủ teorie lingvistického determinismu, nebơ formuloval tezi, podle níž čím více jazyk ovládáme, tím více jsme jím ovlivňováni. $Z$ tohoto hlediska lze Humboldtovy úvahy nad vztahem jazyka, člověka a společnosti označit za nadčasové. Humboldtův př́nos $\mathrm{k}$ dějinám antropologického myšlení lze spatřovat také $\mathrm{v}$ jeho snaze spojit obecnou teorii jazyka s antropologickým prístupem, který formuloval ve svém spise Program komparativní antropologie (1797). Humboldt zde postavil do centra antropologického bádání srovnávací výzkum národních charakterů a úrovně jejich kulturního, vzdělanostního a výchovného potenciálu. Podle Humboldta každý národní charakter představuje unikátní systém tradic, zvyků, náboženské víry, umění a jazyka, které sdílí př́ślušníci určitého národa. Národní charakter, jako jedinečný vnější projev vnitřních duchovních sil a schopností národa, je provázán s jazykem do té míry, že je téměř nelze od sebe oddělit. Proto také jejich výzkum musí probíhat komplexně, ve vzájemných souvislostech a konkrétním historickém kontextu. Humboldtova teorie národního charakteru byla dále rozpracována $\mathrm{v}$ rámci psychologie národů (Völkerpsychologie) a prostřednictvím etnopsychologie ovlivnila i zakladatele moderní americké kulturní antropologie Franze Boase a jeho žáky.

K významným průkopníkům srovnávací historické lingvistiky patřil britský učenec sir William Jones (1746-1794), který ve funkci prezidenta Královské asijské učené společnosti (Royal Asiatic Society of Great Britain and Ireland) inicioval výzkumy indické kultury a formoval základy nové vlny orientalistiky. Pro dějiny lingvistiky jsou významné zejména jeho studie orientálních jazyků a překlady z perštiny, arabštiny, turečtiny a sanskrtu. V roce 1786 na základě komparace sanskrtu s klasickou řečtinou, latinou a řadou dalších jazyků (gótštinou, keltštinou, perštinou aj.) formuloval hypotézu, která předpokládá, že všechny tyto jazyky pocházejí z původního společného jazyka (protojazyka), jejž nazval indoevropský. Podle této teorie lze všechny jazyky, které pocházejí ze stejného jazyka, zařadit do stejné jazykové skupiny. Jones do indoevropské jazykové rodiny zahrnul asi 150 evropských a jihoasijských jazyků, včetně keltských, germánských a slovanských jazyků v Evropě, řady severoindických jazyků, ale také perštiny, urdštiny a bengálšstiny. Jonesovi pokračovatelé na základě komparativní analýzy slov sdílených se semitskými jazyky na Blízkém východě dospěli $\mathrm{k}$ závěru, že Indoevropané byli prapůvodně pastevci žijící kolem roku 6000 př. n. l. na území dnešního Turecka v Anatolii. Mezi zakladatele historické lingvistiky je možné zařadit také německého učence Jakoba Grimma (1785-1863), který v roce 1822 formuloval teorii hláskové přeměny, $k$ níž dochází $v$ průběhu vývoje jazyků. Podle Grimma došlo $\mathrm{k}$ vyčlenění germánských jazyků ze skupiny indoevropských jazyků prostřednictvím hláskových přeměn, které označil jako první posouvání hlásek. $\mathrm{K}$ utváření základů srovnávací lingvistiky přispěl také německý jazykovědec, religionista a orientalista Friedrich Max Müller (1823-1900), který působil na univerzitě v Oxfordu. Významná je zejména jeho kniha Úvod do religionistiky (1873), v níž zkoumal vztah mezi jazykem a náboženstvím. Müller ve svých přednáškách a knihách anticipoval nejen zrození lingvistické antropologie, ale také antropologie náboženství.

V průběhu 19. století vznikla řada prací, které se pokoušely prokázat existenci vzájemných vztahů jak mezi již mrtvými starověkými jazyky, tak mezi jazyky, jimiž se dosud hovoří např́iklad na území Evropy nebo jihozápadní Asie. V této době také věnovala řada vědců, jako např́klad německý jazykovědec August Schleicher (1821-1868), pozornost rekonstrukci slov hypotetického protojazyka, o kterém se předpokládalo, že jím lidé hovořili ještě před vznikem prvních písemných záznamů. Tyto výzkumy vycházely z poznání, že živé jazyky se neustále proměňují, a přitom vykazují tendenci k pravidelnosti hláskových změn. Proto se jazykovědci zaměřili na srovnávací výzkum vývojových proměn př́ibuzných jazyků (jazykové rodiny), který byl založen na srovnávací analýze historických písemných záznamů. Pro studium dějin indoevropských jazykủ bylo dủležité, že u některých z nich se zachovaly písemné dokumenty staré až čtyři tisíce let. To jazykovědcům umožnilo postihnout průběh a mechanismus změn, jimiž konkrétní jazyky procházely v dlouhodobé časové perspektivě, a na tomto základě budovat metodologii historické lingvistiky.

Výzkumy vývojových proměn jazykových systémů $\mathrm{v}$ čase jsou označovány jako diachronní lingvistika. Jedná se o metodologický prýstup, který se zrodil a byl rozpracován v rámci historické lingvistiky. Paralelně s diachronními výzkumy jazyka se však rozvíjely výzkumy jazyka ze synchronní perspektivy. Synchronní lingvistika studuje skladbu, strukturu a funkce jazyka v konkrétním časovém úseku („ted’ a nyni“) a programově abstrahuje od vývojových proměn jazykového systému v čase. Tento prístup anticipoval ve svých posmrtně vydaných přednáškách Kurs obecné lingvistiky (1916) švýcarský jazykovědec Ferdinand de Saussure (1857-1913), který je považován za zakladatele strukturální lingvistiky. Ferdinand de Saussure se domníval, že jazyk je z diachronní perspektivy neuchopitelný, a proto se zaměřil na synchronní analýzu jeho struktury. Na jazyk pohlížel jako na integrovaný systém znaků, ve kterém každý prvek odvozuje svůj význam jak ze svého kontrastního postavení vůči jiným znakủm, tak ze své pozice v jazykovém systému jako celku. Ferdinand de Saussure zavedl do lingvistických výzkumů dva důležité pojmy - langue a parole. Langue (jazyk nebo gramatika) vymezil jako systém abstraktních pravidel, jimiž se člověk řídí, aby byla jeho řeč srozumitelná. Parole (řreč nebo promluva) definoval jako mluvenou řeč, která vzniká uplatněním abstrakt- 
ních pravidel langue v aktuální promluvě. Rozdíl mezi langue a parole Ferdinand de Saussure výstižně vysvětlil na př́kladu šachové hry. Její pravidla představují langue, zatímco jejich konkrétní uplatňování $\mathrm{v}$ průběhu hry je ukázkou parole. ${ }^{5}$ $\mathrm{Na}$ dílo Ferdinanda de Saussura programově navázali v roce 1926 jazykovědci a literární teoretici sdružení v rámci Pražského lingvistického kroužku - Jan Mukařovský, Vilém Mathesius, Nikolaj Sergejevič Trubeckoj, Roman Osipovič Jakobson a další. Jejich cílem bylo kritické přehodnocení srovnávací historické lingvistiky a vybudování základů moderní strukturální lingvistiky založené na analýze jazyka jako dynamického synchronního znakového systému. Zvláštní pozornost přitom věnovali funkčnosti jazykových jednotek $\mathrm{z}$ hlediska fonologie, již rozpracoval zejména N. S. Trubeckoj (1890-1938), který zkoumal význam rozlišujících funkcí hlásek a fonematické struktury opozic. Velký vliv na rozvoj strukturální lingvistiky a následně na strukturální antropologii mělo také dílo $R$. O. Jakobsona (1896-1982) a jeho teorie morfologických binárních kontrastů. Díla představitelů Pražského lingvistického kroužku měla celosvětový ohlas a výrazně ovlivnila americkou lingvistickou antropologii a francouzskou strukturální antropologii Clauda Lévi-Strausse.

\section{VÝVOJOVÉ PROMĚNY LINGVISTICKÉ ANTROPOLOGIE}

Zrození moderní lingvistické antropologie je spjaté se jménem zakladatele americké kulturní antropologie Franze Boase (1858-1942) a okruhem jeho spolupracovníků a žáků, kteři vstoupili do dějin antropologického myšlení jako reprezentanti směrů amerického historismu, konfiguracionismu a školy „osobnost a kultura“. Boas považoval empirické a teoretické studium domorodých jazyků za nezbytnou součást antropologických výzkumů kultury. Proto systematicky posiloval výuku lingvistické antropologie na katedře antropologie na Kolumbijské univerzitě v New Yorku, podílel se na založení časopisu pro výzkum indiánských jazyků Journal American Linguistic a osobně redigoval rozsáhlou Př́iručku amerických indiánských jazyků (1911-1941). Podle Boase „znalost jazyka je nezbytným prostředkem $\mathrm{k}$ tomu, aby byla získána přesná a důkladná znalost, protože mnoho informací může být shromážděno tak, že posloucháme konverzaci domorodců..." ${ }^{\circ}$ Boas přispěl $\mathrm{k}$ vytváření metod, které umožňovaly postihnout fonetickou, syntaktickou a sémantickou dimenzi studovaných jazyků. O tom, jak velkou roli tento vědec přikládal studiu jazyka, svědčí skutečnost, že antropologii vymezil jako vědu o rase, jazyce a kultuře. $\mathrm{Na}$ základě terénních výzkumů mezi indiány amerického Severozápadu, formuloval hypotézu, podle níž se gramatické formy a sémantické kategorie aktivně podílí na organiza-

5 Viz Saussure de, F.: Kurs obecné lingvistiky. Odeon, Praha 1989.

6 Boas, F.: Handbook of American Indian Languages. Bureau of American Ethnology, Buletin 40, Government Printing Ofice, Washington 1911 s. 60 . ci lidského vědomí př́ślušníků dané jazykové společnosti. Boas byl přesvědčen, že jazyky klasifikují lidskou zkušenost. Slovy Boase: „Rozsah zkušeností, které musí jazyk vyjádřit, je nekonečný, kdežto jejich vyjadřování je limitováno počtem fonetických skupin. Je tedy zřejmé, že rozširirené klasifikace zkušenosti musí být základem veškeré artikulované řeči. " Ze zjištění, že sociální zkušenost je tř́íděná prostř̌ednictvím jazyka, Boas vyvodil, že $\mathrm{v}$ rámci různých jazyků dochází k odlišné klasifikaci zkušenosti i objektivní reality. Proto je Boase možné označit za průkopníka teorie lingvistického relativismu, která předpokládá, že jazyk determinuje odlišné vnímání a interpretaci světa v různých kulturách.

Klíčovou osobností americké lingvistické antropologie byl Boasův žák, americký lingvista a antropolog německého původu Edward Sapir (1884-1939), který pod vlivem Franze Boase aplikoval své rozsáhlé znalosti klasických metod komparativní lingvistiky na studium nativních jazyků amerických indiánů. Podle Sapira, „jazykověda má strategický význam pro metodologii společenských věd. Za zdánlivou nezákonitostí společenských jevů je určitá pravidelnost konfigurace a tendence, jež je stejně reálná jako pravidelnost fyzikálních procesů ve světě mechaniky. ${ }^{\text {“8 }} \mathrm{V}$ roce 1921 se Sapir pokusil v knize Jazyk: úvod do studia řeči prokázat hypotézu, podle které kultura, stejně jako jazyk, obsahuje jistý podvědomý vzorec, jenž se do myšlení nepřenáśí. Na základě studia symbolického charakteru jazykové komunikace pak koncipoval svou teorii kultury, podle které je veškeré kulturní chování symbolické. $Z$ tohoto hlediska vidí „pravé ohnisko kultury v interakcích jednotlivých individuí, a ze subjektivního pohledu ve světě významů, které může libovolný jednotlivec podvědomě pro sebe abstrahovat ze své účasti na těchto interakcích". ${ }^{\text {"9 }}$ Charakteristickým rysem Sapirova př́stupu ke studiu jazyka byl jeho holistický důraz na systémový charakter jazykových systémů a jeho snaha postihnout formální celistvost každého jazyka. Již v knize Jazyk upozornil na úzké sepětí jazyka, myšlení a kultury a formuloval tezi, podle níž slovní zásoba dané kultury zrcadlí ústřední potřeby a hodnoty členů daného jazykového společenství. Slovy Sapira: „Je zřejmé, že samotný obsah jazyka je těsně spjat s kulturou. Společnost, která neví nic o teozofii, nepotřebuje pro ni žádné slovo. Lidé, kteří nikdy neviděli koně a ani o něm neslyšeli, si museli slovo pro toto zvíře vytvořit či vypůjčit, když se s ním setkali. V tom smyslu, že slovní zásoba jazyka víceméně věrně odráží kulturu, jejímž potřebám slouží, je naprosto pravda, že dějiny jazyka a dějiny kultury postupují paralelně. “10

Zásadní význam pro další rozpracování lingvistické antropologie měla Sapirova hypotéza, podle které jazyk vystupuje jako aktivní činitel při utváření našeho obrazu světa - teorie

7 Boas, F.: Language and Culture. Macmillan, New York 1940, s. 20.

8 Sapir, E.: Culture, Language and Personality, University California Press, Berkeley 1964, s. 76.

9 Tamtéž, s. 151.

10 Tamtéž, s. 234. 
lingvistického relativismu. Její základy Sapir postupně formuloval v pracích Nevědomé modelování chování ve společnosti (1927) a Postavení lingvistiky jako vědy (1929). Podle Sapira, „skutečný svět je do značné míry budován nevědomky na základě jazykových návyků sociální skupiny... Vidíme, slyšíme a pocitujeme právě tak a ne jinak do značné míry díky tomu, že jazykové návyky našeho společenství předem předpokládají provádění určitých výběrů a interpretace. "11 Sapir programově navázal na Boasovu hypotézu, podle níž jazyk implicitně ovlivňuje klasifikaci lidské zkušenosti a determinuje způsob, jak lidé uvažují o prŕrodní a sociokulturní realitě. Prostř̌ednictvím svých empirických terénních výzkumů a teoretických studií vytyčil jako zásadní směr výzkumů lingvistické antropologie studium vztahu jazyka a kultury. Kontroverzní, ale současně nesmírně inspirativní myšlenkou, která prostupovala Sapirovým dílem, bylo tvrzení, že lidé jsou „vydáni napospas tomu jazyku, který se v jejich společnosti stal vyjadřovacím prostředkem... "12 Edward Sapir svými výzkumy, vědeckými pracemi a akademickými přednáškami výrazně přispěl ke konstituování lingvistické antropologie jako respektované subdisciplíny obecné antropologie. Jeho přínos však není možné omezit na jazykovědu. Sapirův intenzivní zájem o integraci poznatků různých humanitních oborů totiž výrazně ovlivnil antropologickou teorii kultury. Za nejvýznamnější ideový odkaz Edwarda Sapira je ale považována teorie lingvistického relativismu předpokládající determinující vliv jazyka, konkrétně slovní zásoby, na vnímání a interpretaci světa.

Rozhodující roli při rozpracování teorie lingvistického relativismu do podoby klasické Sapirovy-Whorfovy hypotézy sehrál Sapirův žák, chemik a lingvistický antropolog Benjamin Lee Whorf (1897-1941). Whorf vystudoval v roce 1919 obor chemické strojírenství na Massachusetts Institute of Technology a začal pracovat jako požární inspektor v Hardfordské hasičské pojištovací společnosti. Již v tomto období si při zjištování př́čin požárů povšiml vlivu nápisů a slov na chování lidí. Například nápis „prázdný sud“ na benzinovém barelu vyvolává v lidech mnohem bezstarostnější chování nežli nápis „plný sud“. Vzhledem ke zbytkovým třaskavým plynům jsou však i prázdné sudy velice nebezpečné, mohou př́i odhození cigarety explodovat a způsobit požár. Soustavnému vědeckému studiu jazyků se Whorf začal věnovat v roce 1924, kdy jej dlouholetá láska k indiánskému umění Střední Ameriky přivedla k výzkumu mayských a aztéckých hieroglyfů. Zásadní zvrat ve Whorfově vědeckém životě znamenal rok 1931, kdy zahájil postgraduální studium lingvistiky na Yaleově univerzitě. Pod vedením Edwarda Sapira se začal zabývat jutoaztéckou jazykovou rodinou. Zvláštní pozornost věnoval výzkumu jazyka severoamerických indiánů kmene Hopi. Výzkum mu od roku 1932 usnadnila spolupráce s rodilým mluvčím hopijštiny, který žil trvale v New Yorku. V roce 1938 krátce navštívil rezervaci indiánů Hopi.

11 Tamtéž, s. 69.

12 Sapir, E.: The Status of Linguistics as a Science, Language 1929, s.209.
Na základě srovnání gramatiky tzv. standardního evropského jazyka (SAE - Standard Average European), která odráží společný indoevropský původ a historický vliv řečtiny a latiny, s jazykem severoamerických indiánů kmene Hopi dospěl k názoru, že je to především gramatika, jež ovlivňuje způsoby lidského vnímání a interpretace vnějšího světa. „Gramatika každého jazyka je nejen reproduktivní nástroj k vytváření myšlenek, ale spíše něco, co naše myšlenky utváří..." ${ }^{13}$ Podle Whorfa lze „sílu jazyka“ prezentovat na prŕikladě odlišného pojímání času v hopijském jazyce a angličtině. Whorf se svým výzkumem pokusil prokázat, že angličtina a další evropské jazyky, na rozdíl od hopijštiny, dávají prostoru a objektům přednost před časem a pohybem. Proto Evropané př́ísně rozlišují čas na minulý, přítomný a budoucí a fixují jej prostřednictvím podstatných jmen. Oproti tomu indiáni kmene Hopi se při vyjadřování času, jeho průběhu a délky trvání vyhýbají prostorovým metaforám a ve svém jazyce dávají před objekty přednost slovům vyjadřujícím děj, pohyb nebo proces. Hopijské vnímání času, jako světa neustálých vývojových proměn a procesů, se v jejich jazyce odrazilo v preferenci sloves nebo příslovcí. Své názory na jazyk a kulturu Whorf publikoval ve studiích Vztah běžného myšlení a chování k jazyku (1939), Věda a lingvistika (1940) a Jazyk, myšlení a skutečnost (1942). Na další vývoj lingvistické antropologie měl velký vliv zejména posmrtně vydaný sborník jeho prací Jazyk, myšlení a skutečnost (1956), který editoroval John B. Carroll.

Whorf svými výzkumy a vědeckými pracemi programově navázal na Sapirovu snahu prokázat determinující vliv jazyka na lidské chování a prožívání. Výsledkem jejich bádání je antropologická koncepce lingvistického relativismu, která je dnes označována jako Sapirova-Whorfova hypotéza. Její podstatu je možné shrnout do dvou základních myšlenek:

1. Modely našeho vnímání a interpretace světa jsou utvářeny jazykovým systémem, v němž jsme byli vychováni a v jehož kategoriích od dětství myslíme (princip jazykového determinismu). Jedinec proto vnímá a přemýšlí o realitě pouze prostřednictvím pojmů a kategorií, které mu poskytl jeho jazyk.

2. Lidé různých kultur jinak vnímají svět v důsledku rozdílu mezi jazykovými systémy, které jsou odrazem různých prostředí (princip jazykové relativity). ${ }^{14}$

Teorie lingvistického relativismu výrazně ovlivnila další výzkumy v oblasti lingvistické antropologie a ve svých důsledcích vedla $\mathrm{k}$ systematickému studiu vztahů jazyka, osobnosti a kultury. Důsledky, které měly teorie jazykového determinismu a jazykové relativity pro antropologické myšlení, výstižně shrnul americký antropolog českého původu Zdeněk Salzmann: „Jestliže jsou světový názor a chování lidí významně

13 Carroll, J. B. (ed.): Language, Thought, and Reality: Selected Writings of Benjamin Lee Whorf. Massachusetts Institute of Technology, Cambridge 1956, s. 214.

14 Viz Vrhel, F.: Základy etnolingvistiky. SPN, Praha 1981, s. 68. 
ovlivněny strukturou jazyka, kterým hovoří, a jestliže se jazyky svou strukturou liší, pak možnost mezikulturní komunikace a porozumění je pravděpodobně značně oslabena, pokud je vůbec uskutečnitelná. Proto se Whorfovým myšlenkám dostalo značné pozornosti a po druhé světové válce vybudily po řadu let mnoho diskuzí. "15

$\mathrm{Na}$ Whorfovu snahu objasnit vztah mezi gramatickou strukturou jazyka a kulturou navázali svými výzkumy další vědci - například američtí lingvističtí antropologové Dorothy D. Leeová ((1905-1975) a Harry Hoijer (1904-1976). Paralelně se snahou potvrdit Sapirovu-Whorfovu hypotézu se setkáváme s pokusy o její vyvrácení nebo reinterpretaci. Stoupenci radikální verze lingvistického relativismu, která předpokládá, že jazyk aktivně určuje procesy myšlení, se obvykle opírají o Whorfovy komparativní analýzy odlišností slovní zásoby a gramatiky různých jazyků, zejména o srovnávání angličtiny s indiánskými a inuitskými jazyky. Kritici Whorfových výzkumů upozornili na to, že jeho překlady byly někdy neobratné, a tak vyvolávaly dojem odlišného myšlení. Whorf se údajně také dopouštěl chyb proto, že nestudoval etnika a národy jako komplexní celky, ale pouze omezené vzorky jejich jazyka. Navíc různost slovní zásoby a pravidel jejich skladby nacházíme nejen mezi různými jazyky, ale i v rámci jednoho jazyka. Při užívání určitého jazykového systému jde tedy víc o volbu výrazových prostředků než o jazykem limitované myšlení. Napríklad rozdílnost slovní zásoby př́slušníků různých kultur, týkající se odlišného počtu označení pro barvy, ještě neznamená, že tito lidé nejsou schopni různé barvy vnímat. Jako často uváděný př́klad determinujícího vlivu jazyka na myšlení patří tvrzení, že Eskymáci mají více označení pro slovo sníh nežli angličtí mluvčí, a proto dokážou lépe rozlišovat mezi různými druhy sněhu. Mnozí vědci však toto tvrzení zpochybnili, a označili je dokonce za mýtus. Např́ílad antropoložka Laura Martinová je přesvědčená, že Eskymáci velké množství výrazů pro sníh prostě nemají, respektive mají jich maximálně 12 , podobně jako angličtina. ${ }^{16} \mathrm{~K}$ podobnému závěru dospěl také Geoffrey K. Pullum, který tvrdí, že „nikdo, kdo má jen trochu ponětí o eskymáčtině (přesněji řečeno o spř́ízněných jazykových rodinách Inuitů a Yupiků, jimiž se mluví od Sibiře po Grónsko), nikdy neřekl, že Inuité pro sníh tak početné výrazy maji ${ }^{\prime 1}{ }^{17}$ Stoupenci umírněné verze lingvistického relativismu jsou přesvědčeni, že jazyk myšlení neurčuje, nýbrž je pouze ovlivňuje. Podle jejich názoru může jazyk obsahovat rozdíly, jež jsou důležité pro určitou kulturu, ale sám tyto rozdíly nevytvárí a ani nelimituje schopnosti lidí je vnímat. Proto angličtí mluvčí potenciálně dokážou diferencovat mezi

15 Salzmann, Z.: Jazyk, kultura a společnost. Ústav pro etnografii a folkloristiku AV ČR, Praha 1997, s. 96.

16 Martin, L.: Eskimo Words for Snow: A Case Study in the Genesis and Decay of an Anthropological Example. American Psychologist 1986, 88, 418-423.

17 Pullum, G. K.: The Great Eskimo Vocabulary Hoax and Other Irreverent Essays on the Study of Language. University of Chicago Press, Chicago 1991, s. 160. různými druhy sněhu stejně jako Eskymáci. Důkazem pro toto tvrzení nám může být slovní zásoba, již pro označení různých druhů sněhu užívají američctí lyžaři, kteří nemluví pouze o sněhu, ale také o „prašanu“ a „firnu“. Toto rozrůstání anglické slovní zásoby souvisí se změnami ve vnímání. Obyvatelé polárních oblastí a lyžaři si všímají proměn sněhu více než např́ílad lidé žijící na Havaji. $Z$ tohoto hlediska je podstatné zjištění, že změny ve vnímání nejsou závislé na jazyku, jímž lidé hovoří, ale že jazyk závisí na změnách vnímání. $Z$ perspektivy umírněné verze lingvistického relativismu je proto možné formulovat následující hypotézy:

1. Jazyk může zaměřovat pozornost $\mathrm{k}$ určitým způsobům vnímání, pojmům a atribucím a činit některé způsoby myšlení snadnější než jiné.

2. Jazyk může napomáhat paměti nebo ji ovlivňovat do té míry, že se některé pojmy a kategorie vybaví snadněji. ${ }^{18}$

Americká lingvistická antropologie získala v průběhu první poloviny 20. století tak vysoký kredit, že ovlivnila také výzkumy jazyka, myšlení a kultury ve francouzské sociální antropologii. Ta sice navazovala především na domácí tradici etnologickou (M. Mauss), sociologickou (É. Durkheim) a lingvistickou (A. Meillet, J. Giliéron), ale prrijímala také impulzy přicházející z americké antropologie. Originální syntézu antropologických, lingvistických a sémantických přístupů ke studiu kultury představuje především francouzská strukturální antropologie Clauda Lévi-Strausse. V britské sociální antropologii položil základy lingvistické antropologie Bronisław Malinowski, autor řady studií o tichomořských jazycích a kulturách. Malinowski při studiu domorodých jazyků kladl důraz na analýzu situačního kontextu („context of situation“) a konativní funkce jazyka („language as a mode of action“). Malinowského snaha postihnout situační kontext vyrůstala z poznání, že jazyková interakce je významně ovlivňována nelingvistickými faktory, které jsou spjaty s konkrétním kulturním prostředím, v němž komunikace probíhá. Výzkum konativní funkce jazyka vyplývá ze skutečnosti, že prostřednictvím komunikace lze dosáhnout širokého spektra různých cílů. Malinowski si byl vědom toho, že řečové akty neplní pouze informativní nebo apelativní funkci, ale mohou také prrispívat $\mathrm{k}$ posílení sociální soudržnosti a zachování sociálních vztahů a kontaktů mezi př́slušníky dané komunity. Proto zavedl pojem fatická komunikace („phatic communication“), jímž označil užívání jazykových prostředkủ, které plní kontaktovou funkci a utvrzují vztahy sociální vzájemnosti („social mutuality"). Zvláštní pozornost Malinowski věnoval také specifickým jazykovým rysům zaklínadel a magickým formulím, které ostrované považovali za dochovaná slova svých mytických předků. Tím, že Malinowski věnoval pozornost variabilitě uživání a funkcí jazyka $\mathrm{v}$ různých kulturách, de facto

18 Atkinsonová, R. L. - Atkinson, R. C. - Smith, E. E. - Bem, D. J. - Nolen-Hoeksema, S.: Psychologie. Victoria Publishing, Praha 1995, s. 352; Hill, G.: Moderní psychologie. Portál, Praha 2004, s. 159. 
anticipoval zrození „sociolingvistické relativity“ a etnografie komunikace. ${ }^{19} \mathrm{Na}$ jeho koncepci řeči jako nástroje, jehož prostřednictvím se člověk přizpůsobuje prostředí a mechanismům kultury, ale volně navazují také lingvisticky orientované výzkumy filozofü, zabývajících se lingvistickou analýzou přirozeného jazyka (J. L. Austin).

Ve druhé polovině 20. století došlo $v$ dějinách lingvistiky $k$ teoretické a metodologické revoluci, která je spjatá se vznikem kognitivních věd, jež výrazně změnily př́stup $k$ jazykovědnému bádání. Kognitivní vědy se zrodily jako interdisciplinární myšlenkový proud integrující poznatky o fungování lidské mysli a kognitivních procesech, jako jsou vnímání, myšlení, jazyk a řeč. Součástí systému kognitivních věd, které zahrnují kognitivní psychologii, filozofii, antropologii a sociologii, se stala také kognitivní lingvistika, jež se zabývá studiem jazyka v kontextu mentálních procesů a kognitivních funkcí a struktur lidského vědomí. Podle kognitivní lingvistky Moniky Schwarzové (nar. 1961), působící na Univerzitě Friedricha Schillera v Jeně, lze základní východiska kognitivní lingvistiky shrnout do následujících tezí: „Lidské chování je determinováno komplexním systémem mentálních struktur a procedur. Tento systém se člení na řadu subsystémů, které se opírají zčásti o specifické a zčásti obecné principy. Jazyková kapacita je neurobiologicky zakotvená ve strukturních a funkčních zákonitostech lidského mozku. Jazyk jako kognitivní systém se dá popisovat i na abstraktní úrovni nezávisle na své fyziologické bázi, tj. jako mentální fenomén s vlastními zákonitostmi. ${ }^{\text {“20 }}$ Charakteristickým rysem kognitivní lingvistiky je její důraz na výzkum jazyka jako součásti širších kognitivních procesů, mechanismů a struktur. Cílem kognitivní lingvistiky je „na jedné straně popsat inherentní vlastnosti př́slušného mentálního systému znalostí, na straně druhé popsat způsoby jeho interakce s ostatními kognitivními subsystémy“.21 Současná kognitivní lingvistika systematicky sjednocuje poznatky teoretické lingvistiky, psycholingvistiky, psychologie jazyka, kognitivní antropologie, neurolingvistiky a výzkumů $\mathrm{v}$ oblasti umělé inteligence. Lingvistické antropology kognitivní lingvistika ovlivňuje a inspiruje zejména svojí snahou pochopit, jakou roli hraje jazyk v procesu poznávání světa. Pod vlivem kognitivní lingvistiky a dalších kognitivních věd se od šedesátých let 20. století formovala kognitivní antropologie a její subdisciplíny - etnověda a etnosémantika -, které zásadním způsobem přispěly $\mathrm{k}$ hlubšímu pochopení toho, jak lidé prostř̌ednictvím jazyka vytvářejí obraz světa jako specifického kulturního konstruktu.

Obecně je možné konstatovat, že lingvistika od samého počátku zásadním způsobem ovlivňovala vývoj antropologie. Fyzické antropology a archeology inspirovala zejména diachronní lingvistika, zatímco sociální a kulturní antropologo-

19 Viz Černý, M.: Homo loquens: Vybrané kapitoly z lingvistické antropologie. Ostravská univerzita, Ostrava 2009, s. 60; Pokorný, J.: Lingvistická antropologie. Grada, Praha 2009, s. 45-46.

20 Schwarzová, M.: Úvod do kognitivní lingvistiky. Dauphin, Praha 2009 , s. 32 .

21 Tamtéž, s. 33. vé úspěšně využivali poznatky a metody synchronní lingvistiky, která stimulovala rozvoj strukturální antropologie. Nová kapitola vzájemně podnětného dialogu mezi antropologií a lingvistikou je spjatá $s$ expanzí kognitivních věd a aspiracemi symbolických a kognitivních antropologů studovat kulturu jako symbolický a kognitivní systém.

Mezi tematické okruhy, jimiž se současná lingvistická antropologie zabývá, patři problematika studia vztahů jazyka a kultury prostřednictvím výzkumů kognitivních systémů modelů lidského vnímání a myšlení v různých společnostech. Důraz je kladen zejména na sémantickou a komponentní analýzu nativních terminologických systémů a na studium klasifikačních principů, na jejichž základě budují členové určité kultury své domorodé systémy znalostí - folktaxonomie. Přestože je tento trend typický především pro americkou kulturní antropologii, můžeme podobné tendence sledovat i v evropské antropologii. Vše nasvědčuje tomu, že možnosti integrace lingvistických a antropologických metod výzkumu nejsou vyčerpány a lingvistická antropologie zůstane trvalou součástí antropologických výzkumů člověka, společnosti a kultury.

\section{GENEZE JAZYKA V ZRCADLE ANTROPOLOGIE}

Zcela specifickou oblastí výzkumů lingvistických antropologů, na kterých se však zásadním způsobem podílí také fyzičtí antropologové, paleoantropologové a primatologové, je rekonstrukce vzniku a vývoje lidského jazyka. Antropologové si vždy byli vědomi toho, že jazyk představuje jeden ze základních atributů lidského rodu. $O$ to více věnovali pozornost otázkám spjatým s evolučními proměnami komunikace našich homininních předků, genezí lidského jazyka a vznikem plné lingvistické kompetence.

$\mathrm{V}$ průběhu evoluce lidstva došlo ke třem základním zvratům. Ten první se odehrál před 7-5 miliony let, $v$ době, kdy se první homininé oddělili od našich nejbližších příbuzných - afrických lidoopů. Tento kvalitativní skok, který zahájil etapu antropogeneze, je spjatý se vznikem bipedie. Dnes již asi nezjistíme, co bylo příčinou toho, že raní homininé začali k lokomoci užívat dolní končetiny, ale je zřejmé, že tím vznikl potenciál, který umožnil druhý evoluční skok. Ten se odehrál před 2,6-2,5 milionu let, $\mathrm{v}$ době, kdy raní zástupci rodu Homo začali vyrábět první kamenné nástroje, slavnou oldovanskou industrii. Na evoluční scéně se objevil unikátní tvor - primát, který se k vnějšímu světu adaptoval prostřednictvím nadbiologicky vytvořených prostředků a mechanismů. Od této chvíle můžeme sledovat kumulativní růst materiální kultury, jejiž jádro tvoří svět uměle vytvořených předmětủ - artefaktů. Třetí evoluční skok, který dokončil transformaci člověka v biokulturní bytost, se odehrál $\mathrm{v}$ poměrně nedávné době, před $100-$ 40 tisíci lety. $\mathrm{V}$ tomto období naši předkové již disponovali plnou lingvistickou kompetencí a začali akumulovat kognitivní potenciál, který jim v období mladého paleolitu umožnil vstoupit do světa sémiotické kultury. Na evoluční scéně se objevil anatomicky moderní člověk - Homo symbolicus, který 
si začal osvojovat svět prostř̌ednictvím znaků a rozšiřovat materiální kulturu o symbolickou a znakovou bázi. Na znacích, at’ už vystupují v podobě slov, vizuálních obrazů, nebo prostorových objektů, je fascinující, že převrstvují objektivní realitu. Svět, který je kolem nás, se díky znakům mění v kulturní konstrukci - systém symbolů a významů, jejž lidé vytvářejí a společně sdílí v průběhu sociální interakce. Zamyslíme-li se z této perspektivy nad světem, který nás obklopuje, zjistíme, že se jedná o realitu dvojího řádu. První řád reality představuje svět objektivních věcí a jevů. Druhý řád reality je světem znaků, které členům určité společnosti slouží k výkladu a organizaci světa. Z této perspektivy je evidentní, že kulturní prvky a komplexy, které člověk v průběhu evoluce vytvořil, neplní pouze adaptivní a utilitární funkci. Jejich nedílnou součástí je funkce znaková, nebot jsou také „něčím, co stojí místo něčeho jiného“ - novou realitou a jevem „sui generis“, který se vyvíjí podle svých vlastních zákonů.

Tři kvalitativní skoky v minulosti lidstva - vznik bipedie, výroba nástrojů a užívání jazyka jako nástroje lidské komunikace - zásadním zpơsobem změnily osud rodu Homo a následně i tvář planety Země. Význam výzkumu evoluce lidského jazyka výstižně shrnul Zdeněk Salzmann následujícími slovy: „Jazyk je základním atributem člověka a řeč je neoddělitelně spojena s lidským chováním, a tak by nás osvětlení povahy jazyka mohlo přivést blíže $\mathrm{k}$ pochopení kořenů naší lidské podstaty. Proto okolnosti, za nichž jazyk vznikal, poutaly pozornost lidstva po celá tisíciletí..." ${ }^{22}$

Geneze lidského rodu a vznik kultury jsou spjaty s ranými zástupci rodu Homo, kteří před 2,5-1,6 milionu let obývali území východní Afriky. Vznik a následnou adaptivní radiaci lidského rodu nám ilustrují fosilní pozůstatky a artefakty těchto homininů (druhy Homo rudolfensis a Homo habilis), jež byly nalezeny v paleoantropologických lokalitách na území dnešní Keni, Tanzanie a Malawi. Evoluce raných zástupců rodu Homo probíhala v ekologicky náročných podmínkách otevřených savan a lesostepí s náhlými sezonními výkyvy. Postupný nárůst objemu mozku př́slušníků rodů Homo dokumentuje, jakým směrem přirozený výběr působil a kde je třeba hledat biologický potenciál, který vedl k neustálému zvyšování schopnosti komunikace. Náznaky Brocova centra řeči, nalezené na odlitku mozkovny Homo habilis, naznačují, že př́slušníci tohoto druhu byli teoreticky schopni vyslovovat jednoduchá slova. Tomu, aby Homo habilis rozvinul tento potenciál do podoby artikulované řeči, ovšem stály v cestě dva zásadní limity. První omezení vyplývalo $\mathrm{z}$ anatomické stavby hrtanu Homo habilis. $\mathrm{Z}$ fosilních nálezů je zřejmé, že př́liš vysoké umístění hrtanu (laryngu) v hrdle a malá velikost hltanu (faryngu) neumožňovala Homo habilis lidskou artikulaci. Homo habilis byl po celý svůj život v podobné situaci jako lidský novorozenec. Ten také není schopen přesné artikulace, dokud mezi 12. a 18. měsícem nedojde k sestupu jeho hrtanu a vytvoření hrdelní rezonanční dutiny, mající zásadní význam pro artikulaci hlásek v lidské řeči. Druhé omezení, které limitovalo rozvoj lingvistických

22 Salzman, Z.: Jazyk, kultura a společnost, Ústav pro etnologii a folkloristiku AV ČR, Praha 1997, s. 39. dovedností příslušníků Homo habilis, je spjato s tzv. konceptuální adaptací neboli ustavením lidské mysli, které evolučně předcházelo vytvoření jazykové kompetence.

Ustavení lidské mysli u raných homininů bylo limitováno tím, že př́slušníci druhu Homo habilis pravděpodobně vnímali a interpretovali svět v kategoriích „zde a nyní. Proto také $\mathrm{v}$ jejich psychice nad schopností abstrakce a časové distance převládala aktuální prrítomnost, pojímaná a zaznamenaná jako série konkrétních epizod. Kanadský psycholog Merlin Wilfred Donald (nar. 1939) pro tuto vývojovou fázi evoluce raných homininů navrhl označení „epizodická kultura“. Kromě evolučně starší „procedurální paměti“, umožňující hromadit naučená schémata a osvědčené reakce pro jednání, př́slušníci druhu Homo habilis již byli vybaveni „pamětí epizodickou“, která uchovává konkrétní časoprostorová specifika událostí, včetně určitého stupně vědomé sebereflexe. Zatímco procedurální pamět primárně uchovává obecné modely chování a do značné míry ignoruje specifika konkrétní situace, epizodická pamět uchovává specifické detaily situací a životních událostí. Je pravděpodobné, že epizodická pamět umožnila kvalitativně novým způsobem používat naučené vzorce chování, užívané při získávání a rozdělování potravy, výchově dětí a dalších sociálních aktivitách.

Podle Donalda raní homininé, podobně jako současní lidoopi, žili převážně přítomností, vnímanou a interpretovanou jako sled konkrétních situací a epizod. Nejvyšší stupeň jejich pamětového potenciálu nepřesahoval úroveň konkrétní časově omezené vzpomínky nebo představy události. Epizodická pamět proto zahrnovala takové časoprostorově omezené a specifické epizody, jako jsou věci, místa, tváře, situace, vůně, barvy, hlasy apod. Schopnost vybavovat si konkrétní věci a události ve vzpomínkách se tak stala základem sociální zkušenosti raných homininů. Elementární stavební jednotku epizodické kultury tvořil smyslový vjem konkrétní časově omezené události. ${ }^{23}$ Následná evoluce rodu Homo však již představuje neustálé rozšiřování kognitivních schopností směrem k plné konceptuální a jazykové adaptaci, umožňující existenci produktivní a tvořivé lidské komunikace na znakové bázi. Zde je možné vidět zárodky hranice, která $\mathrm{v}$ procesu antropogeneze oddělila člověka od ostatních primátů. Současní afričtí lidoopi, navzdory své schopnosti učit se a užívat $\mathrm{v}$ laboratorních podmínkách znaky a pojmy, totiž v průběhu své evoluce nebyli schopni vyvinout své vlastní symbolické systémy a ustrnuli na prahu protokultury.

Před 1,8-1,4 milionu let se ve východní Africe objevili evolučně pokročilejší př́íslušníci druhu Homo ergaster, kteří disponovali výkonnějším typem lokomoce a modernější stavbou těla. $\mathrm{V}$ tomto období došlo $\mathrm{k}$ dalšímu zvětšování velikosti a váhy těla, růstu objemu lebky a vytváření typicky lidské struktury mozku. Tito homininé, díky svým fyziologickým, morfologickým a mentálním schopnostem a stále efektivnější materiální technologii (acheulské kultuře), dokázali migrovat

23 Donald, M.: Origins of the Modern Mind: Three Stages in the Evolution of Culture and Cognition. Harvard University Press, Cambridge 1991 . 
z Afriky a osídlit rozsáhlé oblasti Eurasie. Na území jihovýchodní Asie žili př́slušníci této lidské formy ještě před 400 tisíci lety a získali zde velmi osobitou morfologii typickou pro př́slušníky druhu Homo erectus. Z evoluční perspektivy je důležité, že u př́ślušníků druhu Homo ergaster a Homo erectus došlo společně se zvyšováním objemu mozkovny a růstem neokortexu také $\mathrm{k}$ proměnám anatomie horního dýchacího traktu, které naznačují evoluční posun směrem $\mathrm{k}$ anatomicky modernímu člověku. Jednalo se především o snížení hrtanu a zvýšení schopnosti produkovat hrtanové zvuky. ${ }^{24}$

Tyto anatomické změny ovšem ještě neumožnily rozvoj schopnosti artikulace a plné lingvistické kompetence. Skutečně lidský vokální trakt s optimální pozicí sníženého hrtanu se totiž $\mathrm{u}$ našich fosilních předků pravděpodobně vyvinul až před 500-300 tisíci lety, tedy v době, kdy se na evoluční scéně objevuje archaický Homo sapiens (Homo heindelbergensis). Tento fakt ovšem nijak nesnižuje význam anatomických a neurofyziologických změn vedoucích $\mathrm{k}$ nárůstu kognitivních a komunikačních schopností př́slušníkủ druhu Homo ergaster a Homo erectus. Vytváření předpokladů pro vznik plné lingvistické kompetence souviselo jak s postupnou přestavbou hrtanu, tak $s$ pokračujícím nárůstem mozkové kontroly vokálně-zvukového traktu a zvyšováním schopnosti generovat vnitřní, vzájemně spjaté modální asociace. Přestože reprezentanti druhů Homo ergaster a Homo erectus ještě neprodukovali hlásky lidské řeči, není vyloučeno, že již používali nějaký lingvistický systém založený na vokálním rozlišování objektů. Tuto hypotézu ovšem do značné míry zpochybňuje skutečnost, že tito homininé nebyli schopni artikulované řeči, ale pouze vokalizace připomínající skřeky současných lidoopů. Britská antropoložka Ann MacLarnonová na základě analýzy nejnižšího obratle hrudníku příslušníka druhu Homo ergaster dospěla $\mathrm{k}$ závěru, že př́slušníci tohoto druhu neovládali své dýchání natolik, aby dokázali dýchat a současně tvořit smysluplné věty. Ann MacLarnonová své tvrzení založila na srovnání hrudních obratlů současného člověka s hrudním obratlem T7 pocházejícím ze 1,5 milionu let staré kostry nariokotomského chlapce (KNM-WT 15000 ), kterou v roce 1984 objevil výzkumný tým keňského paleoantropologa Richarda Erskina Leakeyho (nar. 1944) na západním břehu jezera Turkana v Keni. Otvor, kterým procházejí nervy umožñující kontrolu hrudního svalstva při dýchání, je $\mathrm{v}$ obratli mnohem menší nežli u anatomicky moderního člověka. Nedostatek nervové tkáně nezbytné ke kontrole dýchání zabraňoval př́slušníkům druhu Homo ergaster spojovat slova do delších vět. To samozřejmě neznamená, že Homo ergaster nemohl komunikovat. Jak konstatovala MacLarnonová, domluvit se je možné i prostřednictvím jednoduchých skřeků a zvukủ. Tento typ komunikace ovšem nemá nic společného se současnou lidskou řečí. ${ }^{25}$ Významné je také zjištění, že

24 Laitman, J.: Evolution of the Hominin Upper Respiratory Tract: The Fossil Evidence. In: Tobias, P. (ed.): Hominin Evolution: Past, Present and Future. Alan R. Liss, New York 1985, s. 281-286.

25 MacLarnon, A.: The Vertebral Canal. In: Walker, A. - Leakey, R. E. F. (eds.): The Nariokotome Homo erectus Skeleton. Harvard Uni- $\mathrm{k}$ rozšíření míchy v hrudní oblasti došlo asi před 500 tisíci lety. Proto lze formulovat hypotézu, že neurální předpoklady nezbytné pro koordinaci dýchání a mluvy se objevují až v této fázi antropogeneze. ${ }^{26}$ Skutečnost, že před půl milionem let vznikly anatomické struktury nutné pro artikulovanou komunikaci, potvrzuje i zvětšení hypoglosálního kanálku, jehož objem př́slušníky druhu Homo sapiens výrazně odlišuje od jeho evolučních předchůdců. ${ }^{27}$

$\mathrm{V}$ neprospěch existence lingvistického komunikačního systému u druhů Homo ergaster a Homo erectus mluví také skutečnost, že u těchto homininů hrála dominantní roli pravá mozková hemisféra. Neurologická centra lingvistické kompetence se však nalézají v levé hemisféře. Fakt, že primární gestikulační systém včetně emocionální vokalizace, hlasového zabarvení, mimiky obličeje a gestikulace rukou souvisí s funkcí pravé hemisféry, implikuje hypotézu, že lingvistické komunikaci vývojově předcházel nonverbální komunikační systém. Americký antropolog a lingvista Robbins Burling (nar. 1926) je přesvědčen, že tento nonverbální typ komunikace („gesture-call system“), zahrnující rozsáhlý rejstř́ik gestiky, mimiky a rytmických zvuků, má svůj původ ve způsobu komunikace nižších primátů. ${ }^{28}$ Burlingovy úvahy o nonverbálním typu komunikace originálním způsobem dále rozvinul Merlin Donald, který vypracoval teorii, podle níž Homo erectus disponoval tzv. mimetickou kulturou. Tato specificky lidská, ale svou podstatou nejazyková kultura představuje osobitý mezičlánek mezi epizodickou kulturou plio-pleistocenních homininů a lingvistickou (symbolickou) kulturou Homo sapiens. Podle Donalda mimetické schopnosti př́slušníků druhu Homo erectus umožňovaly prezentaci a reprodukci světa prostřednictvím nejazykových komunikačních prostředků, jakými jsou např́ílad výrazy obličeje, nonverbální zvuky, hlasové zabarvení, pohyby očí, gesta rukou, postoje těla a typizované pohyby celého těla. Významnou složku mimetické dovednosti představoval rytmus, který se vztahoval jak $\mathrm{k}$ hlasové, tak vizuální a pohybové složce komunikace. Základem mimetického znázornění byla schopnost rozkládat pohybové akce na elementární složky, které bylo možné znovu různými způsoby kombinovat a tak reprodukovat nejpodstatnější prvky určité události, věci nebo jevu. Donald je přesvědčen, že Homo erectus disponoval centrální mimetickou kontrolou (mimetickým kontrolorem), umístěnou v přední části mozkové kůry. Centrální mimetická kontrola umožňovala integrovat různé způsoby performace mimetického chování, sjednocovat a koordinovat činnost různých motorických subsystémů, zajišstovat

versity Press, Cambridge 1993, s. 359-446.

26 MacLarnon, A. - Hewitt, G .: The Evolution of Human Speech: The Role of Enhanced Breathing Control. American Journal of Physical Anthropology 1999, 109, s. 341-363.

27 Kay, R., F. - Cartmill, M. - Balow, M.: The Hypoglossal Canal and the Origin of Human Vocal Behaviour. Proceedings of the National Academy of Science 1998, 95, s. 5417-5419.

28 Burling, R.: Primate Calls, Human Language, and Nonverbal Communication. Current Anthropology 1993, s. 25-53. 
srovnání a modelování vnějších i vnitřních akcí a událostí. ${ }^{29}$ Mimetický systém svým potenciálem v kognitivní hierarchii překonal možnosti evolučně staršího epizodického systému plio-pleistocenních homininů, nebot' byl schopen transformovat konkrétní časově omezené výstupy epizodické paměti do podoby akčních metafor a znázornění. Tím, že se výstupy epizodické mysli ocitly pod centrální mimetickou kontrolou, se percepce rozširrila o procesy reprodukování a přehrávání. $\mathrm{Na}$ evolučně starší jádro epizodické kultury se tak nabalila vrstva mimetických schopností, vystupující v podobě unifikované, ale současně tvořivé gestikulace, která tvořila základ sdíleného veřejného komunikačního systému. Podle Donalda měl rozvoj mimetických schopností následující sociální důsledky:

1. utváření sdíleného modelu zvyků a sociální hierarchie;

2. rozvoj vzájemných mimetických her a skupinových mimetických aktů;

3. růst spolupráce a koordinace činností;

4. jednoduchou výchovu a relativně pomalé tempo zlepšování schopností.

Mimetická kultura, sdílená př́slušníky druhu Homo erectus, přitom navenek vystupovala $\mathrm{v}$ podobě:

1. výroby nástrojů a užívání ohně;

2. schopnosti účinné adaptace na různé klimatické a př́írodní podmínky;

3. relativně složité sociální struktury;

4. koordinovaného sezonního lovu;

5. primitivních rituálů vystupujících v podobě skupinových mimetických aktů.

Dominantní postavení centrální mimetické kontroly trvalo až do doby konstituování lingvistické kompetence, která vedla $\mathrm{k}$ transformaci mimetické kultury v kulturu plně jazykovou a symbolickou. V této souvislosti je ovšem třeba si uvědomit, že mimesis, přestože sloužila k sociální komunikaci, nemůže být zaměňována s jazykem. I když jsou mimetické akty svojí podstatou veřejným a vrozeným potenciálem záměrné komunikace, nelze je považovat za prrímého předchůdce jazyka. Je to zpo̊sobeno zejména tím, že mimetické dovednosti tkví svými kořeny v primárním gestikulačním systému a neurologické bázi pravé hemisféry, která evolučně nesouvisí s lingvistickým potenciálem. Na rozdíl od jazyka, jenž je plně spjat se symbolickou znakovou kompetencí, mimesis představuje archaičtější formu zobrazování, která má evolučně blíže ke konkrétnímu epizodickému kopírování událostí. Donald je dokonce přesvědčen o tom, že i u moderních lidí je mimesis obvykle výsledkem epizodické zkušenosti. Proto je podle jeho názoru také možné oddělit mimetické dovednosti od symbolických znakových soustav. Pro evoluci člověka však

29 Donald, M.: Origins of the Modern Mind: Three Stages in the Evolution of Culture and Cognition. Harvard University Press, Cambridge 1991. mělo období mimetické kultury nesmírný význam, nebot' vedlo ke vzniku nových sociálních struktur, včetně modelu kolektivně organizované společnosti. Mimetická kultura totiž umožňovala předávání znalostí a dovedností (materiální technologie) a pravděpodobně i generování sociální činnosti, přispívající $\mathrm{k}$ uchování sociální solidarity a vnitřní integrity jednotlivých pospolitostí druhu Homo erectus. ${ }^{30}$

Přestože mimetická kultura představuje nelingvistický stupeň lidské kultury, v průběhu svého trvání výrazně přispěla ke konstituování konceptuální adaptace a rozšiřrení kognitivní kapacity jako základního předpokladu ustavení lidské mysli. K významným inovacím mimetické komunikace pařily zejména intonace a rytmus, včetně melodických a harmonických prozódií. Výrazy tváře a gesta navíc umožňovaly sémantickou interpretaci mnohoznačných výroků, čímž plnily důležitou metalingvistikou funkci. Současně vytvářely prostředí, umožňující vznik prvního, kolektivně sdíleného modelu reality. Čím více př́slušníci rodu Homo v průběhu evoluce přetvářeli svět vnější přírody do podoby kultury, tím více narůstala potřeba symbolických znaků, které by překonaly omezenost výrazových prostředků mimetické kultury a umožnily efektivní komunikaci. K tomu, aby se $\mathrm{v}$ plném rozsahu konstituovala lingvistická kultura, založená na orálním znakovém systému komunikace, však musely být splněny tři základní podmínky:

1. vznik asociačních center pro řeč v parietálním a frontálním laloku a vývoj specifických pamětových a operačních center v mozkové kůře a podkorových oblastech;

2. konstituování kognitivních schopností, lidské mysli a mentální kapacity pro jazyk;

3. přestavba hlasového traktu - pokles hrtanu a rozšíření hltanu do podoby umožňující vytvářet plně artikulovanou řeč.

Fosilní nálezy svědčí o tom, že k postupnému utváření řečových center a růstu kognitivních schopností docházelo od počátku vzniku rodu Homo. Mozek australopitéků ještě odpovídal svou neurální strukturou a poměrem čelních a týlních laloků organizaci mozku velkých afrických lidoopů. Ke kvalitativní změně velikosti a struktury mozku došlo až u raných příslušníků rodu Homo. Např́klad americký fyzický antropolog Ralph Holloway (nar. 1935), který prováděl analýzu lebky KNM 1470, připsané druhu Homo rudolfensis, zde odhalil stopy Brocovy oblasti, otisknuté na vnitřním povrchu lebky. ${ }^{31}$ Paralelně s růstem mozku, expanzí neokortexu a konstituováním mozkové struktury lidského typu docházelo k nárůstu kognitivních schopností a mentální kapacity pro jazyk. Americký paleoantropolog Glynn Llywelyn Isaac (1937-1985) byl přesvědčen, že evoluční proměny forem a typů paleolitických industrií nezrcadlí pouze růst materiálních dovedností, ale indikují směřování $\mathrm{k}$ lingvistické kompetenci. Ta se ovšem v pl-

\section{Tamtéž.}

31 Holloway, R.: Human Paleontological Evidence Relevant to Language Behavior. Human Neurobiology 1983, 2, s.105-114. 
ném rozsahu prosadila až v období mladého paleolitu. Značný konzervativismus technologie, kterou byly zhotovovány oldovanské a acheulské industrie, svědčí o tom, že příslušníci druhů Homo habilis, Homo ergaster a Homo erectus disponovali podstatně omezenějším kognitivním a komunikačním potenciálem nežli druh Homo sapiens. Americký paleoantropolog Thomas Wynn je přesvědčen, že intelektuální schopnosti nezbytné $\mathrm{k}$ výrobě acheulské industrie odpovídají kognitivnímu potenciálu sedmiletého dítěte anatomicky moderního člověka. ${ }^{32} \mathrm{~K}$ podobným závěrům dospěl americký antropolog a lingvista Jeffrey T. Laitman, podle jehož názoru lingvistické schopnosti dospělého př́slušníka druhu Homo erectus jsou ekvivalentem schopností šestiletého dítěte prríslušníků druhu Homo sapiens. ${ }^{33}$ Jak již bylo konstatováno, jedním ze zásadních omezení, které bránilo príslušníkům druhů Homo ergaster a Homo erectus dosáhnout plné lingvistické kompetence, bylo nedostatečně vyvinuté hlasové ústrojí. U současného dospělého člověka je hrtan, jehož hlasivky regulují průchod zvuku při vokalizaci, položen podstatně níže vůči ústní dutině, než tomu bylo u plio-pleistocenních homininů a druhů Homo ergaster a Homo erectus. Tento fakt zásadním způsobem limitoval jejich vokalizační potenciál a představoval fyziologickou bariéru znemožňující těmto homininům produkovat artikulovanou řeč. Jinými slovy, i když v průběhu evoluce druhů Homo ergaster a Homo erectus neustále narůstaly mentální a neurální předpoklady pro řeč a jazyk, skutečnou lingvistickou kompetencí tito homininé nedisponovali.

Před 700-200 tisíci lety vystřídal na evoluční scéně druhy Homo ergaster a Homo erectus archaický Homo sapiens. Pod tímto označením zahrnujeme široké spektrum pokročilých homininů, jejichž anatomie vykazuje osobitou kombinaci erektoidních a sapientních znaků. Od svých evolučních předků se liší především větší kapacitou mozkovny $(1200$ cm³) a velikostí mozku, který již spadá do variační šíře současného člověka. Klasickým reprezentantem archaického člověka je druh Homo heidelbergensis. Z hlediska vývoje fyziologických struktur, umožňujících produkci artikulované řeči, hraje tento hominin zásadní roli. V průběhu evoluce Homo heidelbergensis, před 500-300 tisíci lety, totiž došlo ke kvalitativní přestavbě jeho superalaryngálního vokálního traktu. Toto časové období bylo stanoveno na základě výzkumů Jeffreyho T. Laitmana a jeho spolupracovníků. ${ }^{34} \mathrm{Ti} \mathrm{v}$ průběhu osmdesátých

32 Wynn, T. - McGrew, W. C.: An Ape's View of the Oldowan. Man 24,3 , s. $383-398$.

33 Laitman, J. T.: The Anatomy of Human Speech. Natural History 1984, 93, 8, s. 20-27.

34 Srov. Laitman, J. T.: Evolution of the Hominid Upper Respiratory Tract: The Fossil Evidence. In: Tobias, P. (ed.): Hominin Evolution: Past, Present and Future. Alan R. Liss, New York 1985, s. 281-286; Laitman, J. T. - Heimbuch, R. C.: The Basicranium of Plio-Pleistocene Hominids as an Indicator of Their Upper Respiratory Systems. American Journal of Physical Anthropology 1982, 59, s. 323-344; Laitman, J. T. - Reidenberg, J. S.: Advances in Understanding the Relationship Between the Skull Base and Larynx with Comments on the Origins of Speech. Human Evolution 1988, 3, s. 99-109. let 20. století dospěli na základě empirického studia spodiny lebeční mnoha druhů savců k závěru, že existuje vztah mezi tvarem spodiny lebeční (basicranium) a pozicí hrtanu (laryn$g u)$. Významné bylo zejména zjištění, že když je spodina lebeční poměrně plochá, je hrtan položen vysoko, pokud je však lebka vyklenutá, je hrtan umístěn nízko v poloze, která umožňuje generovat artikulovanou řeč. První anatomická struktura je charakteristická pro všechny savce včetně současných dětí mladších dvou let. S druhou anatomickou strukturou se však setkáváme výhradně u anatomicky moderních lidí starších dvou let. Teorii, že ke vzniku lidského hlasového aparátu s odpovídající polohou hrtanu došlo až v závěrečné fázi evoluce druhu Homo heidelbergensis, Laitman formuloval na základě komparativní analýzy spodiny lebeční různých homininních druhů. Ve svých hypotézách se přitom opíral o zjištění, že u lidí je spodina lebeční zřetelně vyklenutá, zatímco u ostatních primátů, včetně australopitéků a raných zástupců rodu Homo, je v podstatě plochá. Podle jeho názoru nárůst vyklenutí spodiny lebeční v průběhu antropogeneze indikuje, do jaké míry byli prŕslušníci různých homininních druhů schopni artikulovat zvuky. Z tohoto hlediska charakterizoval hlasové ústrojí australopitéků jako velice podobné současným lidoopům. Na lebkách př́slušníků druhu Homo erectus však již zaznamenal „první př́klady začínající bazikraniální flexe, která neexistuje u lidoopí lebky australopitéků, takže se blíží stavu moderního člověka. To nám napovídá, že hrtan druhu Homo erectus mohl začít sestupovat do krku, přičemž se zvětšoval prostor, v němž mohly být laryngální zvuky modifikovány. “35 Plné vyklenutí spodiny lebeční, srovnatelné s lebkou anatomicky moderního člověka, ale Laitman zaznamenal až na homininních lebkách starých 400-300 tisíc let. Podle jeho názoru „možná právě v této době se objevilo moderní hlasové ústrojí a naši předkové začali produkovat plně artikulovanou řeč“ “36

O tom, jak významná byla přestavba hlasových orgánů v průběhu lidské evoluce, svědčí fakt, že tyto anatomické změny proběhly i na úkor velmi důležitých funkcí lidského organismu. $\mathrm{V}$ důsledku vzniku moderního lidského hrtanu, dokonale přizpůsobeného potřebám artikulované řeči, totiž došlo ke zhoršení koordinace dýchání a polykání. Proto u anatomicky moderního člověka někdy může dojít k tomu, že sousto posouvané do ústí hltanu na okamžik zakryje celý dýchací trakt a vyvolá dušení. U ostatních primátů je hrtan umístěn podstatně výše než u dospělého př́slušníka druhu Homo sapiens. Proto také lidoopi klidně dýchají, i když mají ústa plná potravy. Problémy souvisící s koordinací dýchání a polykání jsou však u anatomicky moderních lidí zcela zanedbatelné ve srovnání s evolučními výhodami, které pro ně znamenal vznik orgánů umožňujících artikulovanou řeč. Vznik supralaryngálního vokálního traktu představuje kvalitativní skok v evoluci člověka. Nebyl to však Homo heidelbergensis, kdo překročil hranici mimetické a sémiotické kultury. Vznik orálně sémiotické kultury totiž předpokládá rozbití ikonic-

35 Laitman, J. T.:The Anatomy of Human Speech. Natural History $1984,93,8$, s. 26

36 Tamtéž, s. 27. 
ké omezenosti mimetické kultury a počátek vytváření světa znaků a symbolů. $S$ přesvědčivými doklady vzniku sémiotické kultury se setkáváme až v období mladšího paleolitu na území Evropy před 40-30 tisíci lety na území Evropy. Př́slušníci druhu Homo sapiens zde zahájili „kognitivní revoluci“, jejíž součástí bylo kvalitativně nové používání symbolů, jazyka a sociálních i materiálních technologii. ${ }^{37}$

Dnes již asi nezjistíme, jaké konkrétní faktory a stimuly vedly naše homininní předky $k$ tomu, že začali systematicky využívat akustický potenciál moderního hrtanu k orálně sémiotické komunikaci. Klasické onomatopoické teorie 19. století, vycházející z představy, že lidská řeč vznikla napodobováním př́rodních zvuků (teorie zvukomalby) nebo rozvíjením zvuků imitujících lidské emotivní stavy (teorie citoslovcí), se dnes zdají být značně spekulativní a možná trochu absurdní. Přesto právě tyto teorie nastolily závažnou otázku: Proč začali naši předkové spojovat určité vokalizace $s$ určitými předměty a činnostmi relativně pravidelným a společensky sdíleným způsobem?

Klasickou hypotézu na toto téma předložili američtí antropologové Charles Francis Hockett (1916-2000) a Robert Ascher (nar. 1931), kteří spojují původ jazyka s potravinovými a ekologickými tlaky. Hockett a Ascher se domnívají, že $\mathrm{v}$ průběhu evoluce homininů vyvolal stále tvrdší boj o získání potravy v proměnlivém ekosystému situace, ve kterých spolu byly neustále spojovány potrava a nebezpečí. Podle Hocketta a Aschera časté spojování potravy a nebezpečí mohlo vyvolávat standardizované směsice zvolání. Hláskové systémy, které primáti užívají, obsahují několik zřetelných zvukủ, z nichž každý má svůj vlastní význam. Jedná se přitom o uzavřenou hláskovou soustavu, což znamená, že hlásky se nespojují tak, aby $\mathrm{z}$ nich vznikaly nové významové celky. Hockett a Ascher však zformulovali hypotézu, podle níž se kombinace zvuků, jimiž homininé označovali potravu a nebezpečí, staly výchozí bází umožňující vznik a vývoj otevřené hláskové soustavy. $\mathrm{V}$ jejím rámci se pak již daly tvořit kombinované vokalizace, které umožnily popis nových věcí, jevů a událostí.

Hockettova a Ascherova argumentace předpokládá, že naši dávní evoluční předchůdci měli zvolání označující jídlo složené ze zvukové struktury, kterou si pracovně nazveme $\mathrm{ABCD}$, zatímco zvolání pro nebezpečí tvořila struktura EFGH. Tyto zvuky mohly být různé a obvykle byly prezentovány $\mathrm{v}$ různých souvislostech. Nicméně stále častěǰsí spojování situace potravy a nebezpečí mohlo způsobit, že tato zvolání se pronášela současně a vytvářela tak kombinaci nových zvuků. To, co dřive označovalo potravu (ABCD), mohlo být následováno zvoláním označujícím nebezpečí (EFGH) a redukováno do nové podoby $\mathrm{ABGH}$, které označovalo „potravu a nebezpečíc. Tím se zvýšil počet zvolání na tři: $\mathrm{ABCD}$ jako potrava, ABGH jako potrava s nebezpečím a EFGH jako nebezpečí. Je také logické, že když se GH, které znamenalo nebezpečí, spojilo $\mathrm{s} A \mathrm{~B}$, tedy s potravou, spojení $\mathrm{CD}$ získalo význam „žádné nebezpečí. Hockettova a Ascherova teorie nám umožňuje

37 Svoboda, J. A.: Čas lovců: Aktualizované dějiny paleolitu. Nadace Universita, Brno 2009, s. 69-71. porozumět tomu, jak mohl probíhat vývoj od uzavřeného systému signálů, který byl tvořen omezeným a poměrně malým repertoárem jednotlivých signálů, $\mathrm{k}$ rozvinutému jazyku. ${ }^{38}$

Přestože tato teorie nepostrádá racionální jádro, musíme si být vědomi toho, že se jedná o spekulativní koncepci, která představuje pouze jednu z možných alternativ, jimiž se mohla odvijet cesta našich předků směrem $\mathrm{k}$ plné lingvistické kompetenci. Výchozí Hockettův a Ascherův předpoklad, že vznik jazyka představuje evoluční transformaci původně uzavřeného systému zviŕ̌ecí komunikace $\mathrm{v}$ otevřený kreativní systém, do značné míry ignoruje fakt, že jazyk může být evolučním produktem výrazného rozvoje kognitivních schopností člověka. Jinými slovy, původ a evoluci jazyka je možné vidět také v rozvoji materiální a sociální technologie, jejichž prostřednictvím se první homininé začali přizpůsobovat vnějšímu prostředí. Růst kognitivního potenciálu, zejména schopnosti tvorby mentálních modelů, umožňujících reflexi světa na symbolické bázi, mohl ve svých důsledcích výrazně přispět ke konstituování lingvistické kompetence.

V uplynulých třech desetiletích jsou široce diskutovány dvě vlivné teorie vysvětlující původ lidského jazyka. Podle první teorie se lidský jazyk vyvinul z gest. ${ }^{39}$ Podle druhé jazyk vznikl $\mathrm{z}$ běžné zvukové komunikace primátů zdokonalením určitého druhu zvukových struktur. ${ }^{40}$ Př́ívrženci první teorie jsou přesvědčeni, že při vzniku jazyka sehrál významnou roli lov zvěře prostřednictvím házení kamenů a oštěpů. Tato poměrně náročná aktivita, vyžadující důkladné zvládnutí motoriky, údajně přispěla ke vzniku nervové báze umožňující „jazyk gest", který se poté transformoval v mluvený jazyk. Teorii předpokládající vznik jazyka z gest podle jejích zastánců prý podporuje i fakt, že opice a lidoopi běžně používají gesta jako součást své přirozené komunikace. Kritici této koncepce však oprávněně upozorňují: „Ze skutečnosti, že důkladné ovládání motoriky se týká házení na cíl i řeči, nutně nevyplývá, že gesta a jazyk mají společný původ. Dokonce nemají ani společné nervové obvody, protože oblasti motorického kortexu, které mají na starosti paže a ruce, jsou odděleny od oblastí,

38 Hockett, Ch. R. - Ascher, R.: The Human Revolution. Current Anthropology 1964, 5, s. 135-168; Hockett, Ch. R.: Man's Place in Nature. McGraw-Hill, New York 1973; Salzmann, Z.: Jazyk, kultura a společnost. Ústav pro etnografii a folkloristiku AV ČR, Praha 1997, s. 44.

39 Hewes, G. W.: Primate Communication and the Gestural Origin of Language. Current Anthropology 1973, 14, s. 5-24; Hewes, G. W.: Primate Communication and the Gestural Origin of Language. Current Anthropology 1973, 14, s. 5-24; Corbalis, M. C.: Human Laterality. Academic Press, New York 1983.

40 Dunbar, R. I. M.: The Coevolution of Neocortical Size, Group Size and Language in Humans, Behavioral and Brain. Science 1993, 16, s. 681-735; Burling, R.: Primate Calls, Human Language, and Nonverbal Communication. Current Anthropology 1993, s. 25-53; MacNeilage, P. F.: Evolution of the Mechanisms of Language Output. In: Hurford, J. R. - Studdert-Kennedy, M. - Knigt, C. (eds.): Approaches to the Evolution of Language: Social and Cognitive Bases. Cambridge University Press, Cambridge 1998, s. 222-241. 
jež souvisejí s jazykem, rty a kontrolou dechu. ${ }^{\text {"41 }} \mathrm{Z}$ tohoto hlediska je mnohem pravděpodobnější teorie, podle níž lidský jazyk vznikl zdokonalením přirozené zvukové komunikace našich homininních předků. Výzkumy současných primátů, jako jsou šimpanzi, paviáni a makakové, prokázaly, že jejich zvuková komunikace vykazuje velké množství prozodických i sémantických informací. Při vzniku jazyka mohly sehrát významnou roli zejména kontaktní zvuky a volání, umožňující vytvářet a posilovat emocionální vazby v sociální skupině. Někteří vědci jsou přesvědčeni, že toto „společné zpívání" a „Vokální výskání stálo na počátku procesu, ,jenž po přidání sémantického obsahu nakonec vyústil ve vznik jazyka, jak jej známe dnes“. ${ }^{42}$

Klíčem umožňujícím pochopit příčiny vzniku lidského jazyka může být odhalení jeho sociální funkce. Tu totiž není možné redukovat na pouhé „informování“ nebo „instruování“. Britský evoluční psycholog Robin Dunbar v této souvislosti formuloval a testoval hypotézu, podle níž primární funkcí jazyka a řeči je výměna informací podporujících soudržnost stále se zvětšujících sociálních skupin. ${ }^{43}$ Dunbar svou teorii vzniku jazyka opřel o následující skutečnosti: 1 . Velikost sociální skupiny u všech primátů úzce souvisí s relativní velikostí jejich neokortexu. 2. Lidoopi a opice Starého světa aktivně utváŕí a posilují své sociální vztahy prostřednictvím vzájemné péče o srst („grooming“). 3. Čas věnovaný vzájemné péči o srst u lidoopů a opic Starého světa stoupá s velikostí skupiny. V roce 1993 se Dunbar společně s britskou evoluční antropoložkou Leslie Crum Aiellovou pokusili stanovit dobu, v níž vzrostl počet členů homininní skupiny do té míry, že vzájemná péče o srst jim již neumožňovala udržovat sociální integritu a posilovat společenské vztahy. Dunbar a Aiellová byli přesvědčeni, že právě v této době vznikl jazyk jako kvalitativně nový stmelující sociální mechanismus doplňující tradiční péči o srst. Podle lebečních rozměrů všech známých homininních fosilií nejdřive vypočítali relativní objem neokortexu našich homininních předků. Z nich pak stanovili velikost sociální skupiny a čas potřebný $\mathrm{k}$ vzájemné péči o srst. Vycházeli přitom $\mathrm{z}$ předpokladu, že pokud čas vynaložený na vzájemnou péči o srst nepřesáhl $25 \%$ celkového času bdění, což je o něco více než limit sledovaný u žijících primátů, mohli homininé vzájemnou péči o srst doplňovat kontaktní vokální komunikací („vokálním výskáním“). Ale jakmile čas věnovaný péči o srst přesáhl $30 \%$, k čemuž došlo v důsledku růstu velikosti homininních skupin, musel se objevit nový komunikační mechanismus - lidský jazyk. Ten umožnil interakci s více osobami najednou, efektivnější výměnu informací a růst velikosti sociální skupiny nad maximum, kterého dosahují ostatní primáti (asi 50 jedinců u šimpanzů a paviánů). Aiellová a Dunbar na základě kvantitativní analýzy využívající rovnic pro vztahy mezi velikostí neokortexu, velikostí skupiny a časem tráveným

41 Barrett, L. - Dunbar, R. - Lycett, J.: Evoluční psychologie člověka. Portál, Praha 2007, s. 425.

42 Tamtéž, s. 427.

43 Dunbar, R. I. M.: Groups, Gossip and the Evolution of Language. Faber and Faber, London 1996. vzájemnou péčí o srst, dospěli k závěru, že kritickou hranici, vyžadující vznik nového komunikačního systému (jazyka), naši evoluční předkové překročili asi před půl milionem let. ${ }^{44}$ Zrození jazyka jako nástroje udržení sociální soudržnosti umožnilo raným zástupcům druhu Homo sapiens kvalitativně novým způsobem sledovat dynamiku vztahů v rámci sociální sítě. $\mathrm{Na}$ rozdíl od lidoopů a raných homindů, kteří byli při uzavírání koalicí a identifikaci prátel a nepřátel závislí na své vizuální zkušenosti, jazyk lidem umožnil výměnu informací prostřednictvím „společenské konverzace“, kterou Dunbar označuje jako „drby“ („gossip“). Do této kategorie Dunbar zahrnuje široké spektrum informací a znalostí týkajících se sociální sítě. Přestože informace získané od někoho jiného nejsou tak přesné jako osobní zkušenost, konverzace věnovaná společenským tématům umožňuje lidem sledovat změny, které proběhly v sociální síti v době jejich nepř́ítomnosti, a flexibilně reagovat na nově vzniklé vztahy a sociální situace. Drby plní také důležitou kontrolní funkci, nebot ve velkých sociálních skupinách umožňují varovat pred parazitujícími jednotlivci, kteří nedodržují své závazky. ${ }^{45} \mathrm{~V}$ neposlední řadě je prostřednictvím drbů možné prezentovat osobnostní kvality nebo pozitivní vlastnosti přátel a spojencủ. Jazyk zřejmě plnil důležitou funkci také $\mathrm{v}$ rámci sexuálního výběru při získávání a udržení partnerů. ${ }^{46}$ Evoluční psychologové v této souvislosti formulovali teorii „Šeherezádina efektu“, podle níž verbální schopnosti a dovednosti mužů představovaly významnou „součást specificky lidských strategií při hledání partnera“ ${ }^{47}$ Je pravděpodobné, že od vzniku archaického Homo sapiens jazykový vývoj postupně směřoval ke konstituování prvních sémiotických kultur, pro které jsou typické zcela nové formy přenosu, zpracování a ukládání informací. Součástí mentální výbavy, vyrůstající z lingvistické kompetence, se stala sémantická pamět', tezovitá pamět, porozumění protimluvě, analytické myšlení, indukce a verifikace. Lidské společnosti, které $\mathrm{v}$ průběhu evoluce anatomicky moderního člověka (Homo sapiens sapiens) v plném rozsahu rozvinuly potenciál lingvistické adaptace, již v období mladého paleolitu disponovaly jazyky jako kvalitativně novými nástroji vnímání a interpretace světa a sémiotickými systémy, vystupujícími v podobě mýtů a rituálů, které přispívaly $\mathrm{k}$ upevňování sociální solidarity. ${ }^{48} \mathrm{Sym}$ bolická adaptace výrazně ovlivnila také sociální technologii, včetně utváření relativně pevné sociální struktury, založené

44 Aiello, L. C. - Dunbar, R. I. M.: Neocortex Size, Group Size and the Evolution of Language. Current Anthropology 1993, 34, s. 184-193.

45 Enquist, M. - Leimar, O.: The Evolution of Cooperation in Mobile Organisms. Animal Behaviour 1993, 45, s. 747-757.

46 Miller, G. F.: The Mating Mind. Heinemann, London 2000.

47 Barrett, L. - Dunbar, R. - Lycett, J.: Evoluční psychologie člověka. Portál, Praha 2007, s. 435.

48 Knight, C. D.: Ritual/Speech Coevolution: A Solution to the Problem of Desception. In: Hurford, J. R. - Studdert-Kennedy, M. - Knigt, C. (eds.): Approaches to the Evolution of Language: Social and Cognitive Bases. Cambridge University Press, Cambridge 1998, s. $68-91$. 
na pokrevenství a př́buzenství, institucionalizaci a jasně vymezené teritoriální strategii.

Jak již bylo konstatováno, k využití potenciálu lingvistické a symbolické adaptace nedošlo současně s poklesem hrtanu před 500-300 tisíci lety. Je pravděpodobné, že Homo heidelbergensis ještě nemluvil plně artikulovanou řečí. Ta se zřejmě prosadila až před 200-100 tisíci lety společně s anatomicky moderním člověkem. Zárodky lingvistické kompetence je však přesto třeba hledat právě mezi zástupci druhu Homo heidelbergensis, kteří zřejmě jako první překročili hranici mimetické kultury. V této souvislosti není bez zajímavosti názor Merlina Donalda, podle něhož hlavním smyslem lingvistické adaptace nebylo vytvoření jazyka jako takového, ale spíše konstituování integrovaného, souvislého a původně mytického myšlení, které umožňovalo postihnout celistvý obraz světa. ${ }^{49}$ Jazyk přitom plnil spíše instrumentální funkci, umožňující dosažení tohoto cíle. $\mathrm{Z}$ tohoto hlediska se člověk od lidoopů liší především úrovní mentálních modelů, které je jeho mysl schopná vytvářet, přičemž jedním ze základních projevů této výlučnosti je schopnost vyprávění - narativita, zakládající koherentní kulturní vizi skutečnosti. ${ }^{50}$ Ještě pregnantněji charakterizoval význam jazyka v evoluci lidstva lingvista Derrick Bickerton: „Jen jazyk mohl prolomit vězení bezprostřední zkušenosti, v níž je každá jiná bytost uzavřena, a vypustil nás do nekonečné svobody prostoru a času. ${ }^{\text {" }} 1$

\section{HOMO SYMBOLICUS}

Zamyslíme-li se nad světem, který nás obklopuje, zjistíme, že žijeme v realitě dvojího řádu. První řád reality představuje svět artefaktů tvořících materiální bázi skutečnosti. Druhý řád reality je světem znaků - kulturních významů a symboli̊, které členům určité společnosti slouží k výkladu a organizaci světa. Na kulturu není možné pohližzet pouze jako na užitečný adaptivní systém. $\mathrm{V}$ průběhu evoluce lidstva totiž stále více materiálních prvků a komplexů začalo kromě utilitární funkce plnit funkci znakovou - informovat o sociálním statusu, vkusu, vzdělání, moci nebo bohatství svých uživatelů. Výsledkem je skutečnost, že dnes „žijeme ve světě, v němž se všechno stává znakem a transformuje v symbol“ ${ }^{52}$ Podstatu současné kultury, kterou lze označit za svět „velké znakové hry“, ovlivňují zejména nové systémy přenosu a uchování informací, které vytlačují tradiční formy komunikace. Jak konstatoval český sociolog Miloslav Petrusek, mění se „role tradičního obrazu, produkce a reprodukce hudby, vyprávění je vytlačováno jednoduchým zobrazením atd. “53

49 Donald, M.: Origins of the Modern Mind: Three Stages in the Evolution of Culture and Cognition. Harvard University Press, Cambridge 1991 .

50 Budil, I. T.: Mýtus, jazyk a kulturní antropologie. Triton, Praha 1995, s. 173.

51 Leakey, R.: Pưvod lidstva. Archa, Bratislava 1996, s. 120.

52 Petrusek, M.: Společnosti pozdní doby. SLON, Praha 2006, s. 120.

53 Tamtéž, s. 120.
V průběhu vývoje lidské společnosti lidé různým způsobem vytvářeli a vzájemně si předávali symboly a významy. Lze souhlasit s kanadským teoretikem médií Marshallem McLuhanem (1911-1980), že v dějinách nebylo důležité, „,co“ se kdy sdělovalo, ale ,jak“ se to sdělovalo. V preliterárních společnostech, ve kterých neexistovalo písmo, byl základním médiem lidský hlas a základním receptorem lidský sluch. Přenos informací byl založen na bezprostřední komunikaci, kdy „slyšet“ znamenalo „uvěřit“. Kvalitativní zvrat v dějinách znamenal vynález knihtisku, díky kterému se základním médiem stalo písmo a receptorem zrak. Knihtisk umožnil kvalitativně novým způsobem fixovat informace a předávat je velkému množství lidí. Třetí revoluce $\mathrm{v}$ dějinách transmise symbolických systémů je spjata s elektronickými prostředky masové komunikace, které zahájily éru, v níž masmédia „anihiluji““ čas a prostor a člověk se jejich prostřednictvím stává součástí „světové vesnice“. Slovy McLuhana: „V elektronickém věku mžikově rychlých informací mizí čas (měřený vizuálně a segmentačně) i prostor (jakožto uniformní, obrazový a ohraničený). Ve věku mžikově rychlých informací člověk končí se svojí fragmentarizovanou specializací a prebírá roli sběrače informací. “54 Masmédia zapojují do procesu vnímání téměř všechny smysly, písmo je vytlačováno obrazem a zvukem. Vznik klasických prostředků masové komunikace - tisku, rozhlasu, filmu a televize vyústil ve zformování nového typu kultury, která je označovaná jako kultura masová (populární, běžná). Masová kultura se vytváří nejméně dvě století. Zrodila se jako sekundární produkt průmyslové revoluce společně s industrializací a urbanizací. Polská socioložka Antonia Kłoskowská výstižně vymezila masovou kulturu jako současné sdělování identických nebo obdobných obsahů, které směřuje od malého počtu zdrojů k velkým masám př́jemců. ${ }^{55}$ Charakteristickým rysem masové kultury je její publikum, které je neprrímé a prostorově atomizované. Kvalitativně novou dimenzi vtiskl prostředkům masové komunikace internet a jeho masové užívání. Na počátku třetího tisíciletí je tak možné konstatovat, že došlo ke spojení dvou zásadních mechanismů globalizace světa - procesů celosvětové ekonomické integrace a stále účinnějšího působení prostřredků masové komunikace. Zrodil se „světový informační řád“, který vystupuje v podobě mezinárodního systému výroby, distribuce a spotřeby informací. ${ }^{56}$ Charakteristickým rysem vývoje současné společnosti je informační a mediální „přetíženost“ kultury. Řada teoretiků v této souvislosti mluví o „Velké informační revoluci“. Ta vedla ve vyspělých zemích světa ke vzniku „informační společnosti“, v níž byly ekonomické, politické a sociokulturní procesy zásadním způsobem posíleny, propojeny a zvýznamněny prostřednictvím stále efektivnějších komunikačních a informačních technologii. ${ }^{57}$

54 McLuhan, M.: Jak rozumět médiím. Odeon, Praha 1991, s. 133.

55 Viz Kłoskowská, A.: Masová kultura. Svoboda, Praha 1967.

56 Giddens, A.: Sociologie. Argo, Praha 1999, s. 377.

57 Castells, M.: The Information Age: Economy, Society, and Culture. Blackwell, Oxford 1996-1998; Castells, M. - Himanen, P.: The 
Síla prostředků masové komunikace primárně spočívá v tom, že svět nejen prezentují, ale také ve stále větší míře definují a konceptualizují. Francouzský sociolog a filozof Jean Baudrillard (1929-2007) je přesvědčen, že nové komunikační prostředky přetvářejí samu podstatu lidského života. Expanze masmédií ve svých důsledcích vedla $\mathrm{k}$ transformaci moderní společnosti, jež byla založena na výrobě a spotřebě zboží, ve společnost postmoderní, která je organizována na základě všeobjímajícího toku virtuálních simulací, hry znaků a obrazů. Podle Baudrillarda se $\mathrm{v}$ postmoderní společnosti modernistické taxonomie světa, založené na distinkcích „reálné a nereálné“, „veřejné a soukromé“, „umění a skutečnost“, zhroutily, jako by je nasála „černá díra“. Novým hrdinou postmoderní doby se stalo „simulakrum“ - imitace nebo kopie bez originálu (nebo referentu), které je však „skutečnější než skutečné“. ${ }^{58}$ Ústřední roli v postmoderním světě simulací hrají prostředky masové komunikace a s nimi spjatý proces „imploze“, vedoucí ke zhroucení hranic mezi světem prezentovaným médii a sociální realitou. Baudrillard je např́íklad přesvědčený, že v televizním vysílání splývá zpravodajství, realita, zábava a fikce do té míry, že „televize je svět“. Podstata televizního vysílání údajně nespočívá v simulaci skutečného života nebo reprezentaci reality, ale vytváření autonomního světa „hyperreality“, která je „reálnější než reálné“. Hyperrealita jako „vyretušovaná skutečnost“ a „estetická halucinace“ podle Baudrillarda představuje specifický sémiotický text, který $\mathrm{v}$ době postmoderny lidem zprostředkovává kontakt s realitou. Tato „mediace“ (zprostř̌edkování) může mít nejrůznější podobu, od neutrálního informování přes dohadování až po snahy o sociální manipulaci a ovládání. Nové komunikační prostředky, vytvářející stále rafinovanější podobu hyperreality. Fungují jako návod, ukazatel a mapa, které lidem říkají, ,jak žít“. Hyperrealita poskytuje mnohem intenzivnější zážitky než scény z banálního světa každodennosti. Mediální simulace skutečnosti člověku umožňuje uniknout $\mathrm{z}$ „pouště skutečného" do alternativních světů umělé nápodoby života. Bohužel, prostřednictvím komunikačních sítí, jež nám sdělují, jak interpretovat skutečnost a utvářet vzorce chování, dochází ve stále větší míře $\mathrm{k}$ unifikaci obrazu světa a standardizaci způsobu života. Lidstvo si zcela paradoxně díky své tvořivosti a stále sofistikovanějším komunikačním technologiím vytvořilo nový typ otroctví.

Americký antropolog Clifford Geertz komentoval skutečnost, že člověk je tvůrcem a současně zajatcem symbolické kultury, kterou vytvořil, následujícími slovy: „Člověk je zvíre zavěšené do pavučiny významů, kterou si samo upletlo. " ${ }^{\text {59 }}$ Zamysleme se na okamžik nad touto alegorií, nebot její důsledky si obvykle v každodenním chvatu neuvědomujeme. Důvody jsou

Information Society and the Welfare State: The Finish Model. Oxford University Press, Oxford 2002; Webster, F.: Theories of the Information Society. Routledge, London 2002.

58 Baudrillard, J.: Simulacra and Simulation. University of Michigan Press, Ann Arbor 1994.

59 Geertz, C.: Interpretace kultur. Sociologické nakladatelství, Praha 2000 , s. 15 . prosté. Každý si umí představit člověka spoutaného provazy, okovy nebo uvězněného v železné kleci. Ale člověka spoutaného sítí významů? Umístěného v kleci symbolư? Ne! Tato představa nás tolik neoslovuje, nebot významy a symboly jsou neviditelné. A právě v tom spočívá grotesknost lidské existence na počátku třetího tisíciletí. Na rozdíl od tradičních společností, v nichž bylo sociální kontroly dosahováno viditelnými fyzickými prostředky a veřejnými tresty, v moderní společnosti je sociální dohled, manipulace a kontrola zajištována symbolickými nástroji. Rozhodující roli z toho hlediska hrají stále více komunikační sítě, masmédia, kyberprostor a s nimi spjatá kyberkultura, kterou lze vymezit jako součást kulturní praxe a životního stylu spojeného s využíváním moderních informačních technologií. Skutečnost, že Homo symbolicus ovinul tvář Země sítí symbolů a významů vyvolala zájem o reflexi a interpretaci tohoto fenoménu nejen mezi sociology a psychology, ale také mezi antropology. Zrodila se kyberantropologie - subdisciplína antropologie, jež programově studuje symbolickou dimenzi kultury spjatou s kyberprostorem a informačními sítěmi, které ve stále větší míře determinují chování a prožívání člověka postmoderní doby. Dủležitým předmětem výzkumů věd o člověku a kultuře se stal nový fenomén - podstata, moc a vliv masmédií. Vztah člověka, médií a kultury v postmoderní době výstižně shrnul americký teoretik médií Neil Postman (1931-2003): „Jsem přesvědčen, že jsme dosáhli kritické hranice v tom, do jaké míry elektronická média rozhodně a nezvratně změnila podstatu našeho symbolického prostředí." ${ }^{0}$

60 Postman, N.: Ubavit se k smrti. Mladá fronta, Praha 1999, s. 36.

\section{LITERATURA}

Aiello, L. C. - Dunbar, R. I. M. (1993): Neocortex Size, Group Size and the Evolution of Language. Current Anthropology, 34, 184-193.

Atkinsonová, R. L. - Atkinson, R. C. - Smith, E. E. - Bem, D. J. - Nolen-Hoeksema, S. (1995): Psychologie. Praha: Victoria Publishing.

Barrett, L. - Dunbar, R. - Lycett, J. (2007): Evoluční psychologie člověka. Praha: Portál.

Boas, F. (1911): Handbook of American Indian Languages. Bureau of American Ethnology, Buletin 40. Washington: Government Printing Ofice.

Boas, F. (1940): Language and Culture. New York: Macmillan.

Baudrillard, J. (1994): Simulacra and Simulation. Ann Arbor: University of Michigan Press.

Budil, I. T. (1995): Mýtus, jazyk a kulturní antropologie. Praha: Triton.

Burling, R. (1993): Primate Calls, Human Language, and Nonverbal Communication. Current Anthropology, 34, 25-53.

Castells, M.(1996-1998): The Information Age: Economy, Society, and Culture. Oxford: Blackwell.

Castells, M. - Himanen, P. (2002): The Information Society and the Welfare State: The Finish Model. Oxford: Oxford University Press.

Dunbar, R. I. M. (1993): The Coevolution of Neocortical Size, Group Size and Language in Humans, Behavioral and Brain. Science, 16, 681-735.

Dunbar, R. I. M. (1996): Groups, Gossip and the Evolution of Language. London: Faber and Faber.

Hewes, G. W. (1973): Primate Communication and the Gestural Origin of Language. Current Anthropology, 14, 5-24.

Carroll, J. B., ed. (1956): Language, Thought, and Reality: Selected Writings of Benjamin Lee Whorf. Cambridge: Massachusetts Institute of Technology. 
Corbalis, M. C. (1983): Human Laterality. New York: Academic Press.

Černý, M. (2009): Homo loquens: Vybrané kapitoly z lingvistické antropologie. Ostrava: Ostravská univerzita.

Donald, M. (1991): Origins of the Modern Mind: Three Stages in the Evolution of Culture and Cognition. Cambridge: Harvard University Press.

Duranti, A., ed. (1997): Linguistic Anthropology. Cambridge: CUP.

Duranti, A., ed. (2000): Linguistic Anthropology: A Reader. Oxford: Blackwell.

Enquist, M. - Leimar, O. (1993): The Evolution of Cooperation in Mobile Organisms. Animal Behaviour, 45, 747-757.

Geertz, C. (2000): Interpretace kultur. Praha: Sociologické nakladatelství.

Giddens, A. (1999): Sociologie. Praha: Argo.

Greenberg, J. H. (1968): Anthropological Linguistics: An Introduction. New York: Random House.

Hewes, G. W. (1973): Primate Communication and the Gestural Origin of Language. Current Anthropology, 14, 5-24.

Hockett, Ch. R. - Ascher, R. (1964): The Human Revolution. Current Anthropology, 5, 135-168.

Hockett, Ch. R. (1973): Man's Place in Nature. New York: McGraw-Hill.

Holloway, R. (1983): Human Paleontological Evidence Relevant to Language Behavior. Human Neurobiology, 2, 105-114.

Hurford, J. R. - Studdert-Kennedy, M. - Knigt, C., eds. (1998): Approaches to the Evolution of Language: Social and Cognitive Bases. Cambridge: Cambridge University Press.

Hunt, M. (2000): Déjiny psychologie. Praha: Portál.

Hymes, D. (1964): Language in Culture and Society: A Reader in Linguistic and Anthropology. New York: Harper and Row.

Irvine, J. T., ed. (1993): The Psychology of Culture: A Course of Lectures. Berlin: Mouton de Gruyter.

Kay, R., F. - Cartmill, M. - Balow, M. (1998): The Hypoglossal Canal and the Origin of Human Vocal Behaviour. Proceedings of the National Academy of Science, 95, 5417-5419.

Kłoskowská, A. (1997): Masová kultura. Praha: Svoboda.

Knight, C. D. (1998): Ritual/Speech Coevolution: A Solution to the Problem of Desception. In: Hurford, J. R. - Studdert-Kennedy, M. - Knigt, C. eds., Approaches to the Evolution of Language: Social and Cognitive Bases. Cambridge: Cambridge University Press, 68-91.

MacLarnon, A. (1993): The Vertebral Canal. In: Walker, A. - Leakey, R. E. F., eds.: The Nariokotome Homo erectus Skeleton. Cambridge: Harvard University Press, 359-446.

MacLarnon, A. - Hewitt, G . (1999): The Evolution of Human Speech: The Role of Enhanced Breathing Control. American Journal of Physical Anthropology, 109, 341-363.

Mandelbaum, D. G., ed. (1949): Selected Writtings of Edward Sapir in Lan guage, Culture and Personality. Berkeley: University of California Press.

Miller, G. F. (2000): The Mating Mind. London: Heinemann.

Laitman, L. J. (1985): Evolution of the Hominid Upper Respiratory Tract: The Fossil Evidence. In: Tobias, P., ed.: Hominid Evolution: Past, Present and Future. New York: Alan R. Liss.

Laitman, J. T. (1984): The Anatomy of Human Speech. Natural History, 93 (8), 20-27.

Laitman, J. T. - Heimbuch, R. C. (1982): The Basicranium of Plio-Pleistocene Hominids as an Indicator of Their Upper Respiratory Systems. American Journal of Physical Anthropology, 59, 323-344.

Laitman, J. T. - Reidenberg, J. S. (1988): Advances in Understanding the Relationship Between the Skull Base and Larynx with Comments on the Origins of Speech. Human Evolution, 3, 99-109.
Leakey, R. (1996): Původ lidstva. Bratislava: Archa.

Martin, L. (1986): Eskimo Words for Snow: A Case Study in the Genesis and Decay of an Anthropological Example. American Psychologist, 88, 418-423.

McLuhan, M. (1991): Jak rozumět médiím. Praha: Odeon.

Petrusek, M. (2006): Společnosti pozdni doby. Praha: SLON.

Pokorný, J. (2009): Lingvistická antropologie. Praha: Grada.

Postman, N. (1999): Ubavit se k smrti. Praha: Mladá fronta.

Pullum, G. K. (1991): The Great Eskimo Vocabulary Hoax and Other Irreverent Essays on the Study of Language. Chicago: University of Chicago Press.

Salzmann, Z. (1997): Jazyk, kultura a společnost. Praha: Ústav pro etnografii a folkloristiku AV ČR.

Sapir, E. (1921): Language: An Introduction to the Study of Speech. New York: Harcourt, Brace.

Saussure de, F. (1989): Kurs obecné lingvistiky. Praha: Odeon.

Schwarzová, M. (2009): Úvod do kognitivní lingvistiky. Praha: Dauphin.

Sternberg, R. J. (2002): Kognitivní psychologie. Praha: Portál.

Svoboda, J. A. (2009): Čas lovců: Aktualizované dějiny paleolitu. Brno: Nadace Universitas.

Vrhel, F. (1981): Základy etnolingvistiky. Praha: SPN

Webster, F. (2002): Theories of the Information Society. London: Routledge.

Wynn, T. - McGrew, W. C. (1989): An Ape's View of the Oldowan. Man 24 (3), 383-398.

AUTOR

Soukup, Václav (31. 8. 1957, Mariánské Lázně), český kulturolog a antropolog působící na Filozofické fakultě Univerzity Karlovy v Praze. Ve své výzkumné, publikační a pedagogické činnosti se zaměřuje na sociální a kulturní antropologii a paleoantropologii. Vydal řadu odborných studií a monografí́, které jsou věnovány teorii a dějinám kultury. V knize Dějiny antropologie (2004) synteticky analyzoval dějiny antropologického myšlení, zatímco jeho rozsáhlé kompendium Antropologie: teorie člověka a kultury (2011) představuje komplexní uvedení do biologické a kulturní antropologie. Nakladatelství Karolinum v tomto roce vydalo jeho rozsáhlou encyklopedicky koncipovanou monografii Prehistorie rodu Homo (2015). Ve spolupráci s českou historičkou umění a kulturní antropoložkou Barborou Půtovou a americkým kulturním antropologem Josephem Nevadomskym napsal knihu Benin: království ušlechtilého bronzu věnované dějinám, kultuře a umění afrického království Benin. Společně $\mathrm{s}$ Barborou Půtovou a třiceti předními světovými paleoantropology, archeology a prehistoriky realizovali mezinárodní projekt, jehož výstupem je kniha The Genesis of Creativity and the Origin of the Human Mind.

Kontakt: Doc. PhDr. Václav Soukup, CSc., Ústav etnologie Filozofické fakulty Univerzity Karlovy v Praze, Celetná 20, 11000 Praha 1, e-mail:Vaclav.Soukup@ff.cuni.cz. 